Portland State University

PDXScholar

\title{
The Circulation of Elites in Twentieth Century American History: The New Deal as Case Study
}

Diane Theresa Volk

Portland State University

Follow this and additional works at: https://pdxscholar.library.pdx.edu/open_access_etds

Part of the United States History Commons

Let us know how access to this document benefits you.

\section{Recommended Citation}

Volk, Diane Theresa, "The Circulation of Elites in Twentieth Century American History: The New Deal as Case Study" (1976). Dissertations and Theses. Paper 2440.

https://doi.org/10.15760/etd.2433

This Thesis is brought to you for free and open access. It has been accepted for inclusion in Dissertations and Theses by an authorized administrator of PDXScholar. Please contact us if we can make this document more accessible: pdxscholar@pdx.edu. 
AN ABSTRACT OF THE THESIS OF Diane Theresa Volk, for the Master of Arts in History presented April 26, 1976.

Title: The Circulation of Elites in Twentieth Century American History: The New Deal as a Case Study.

APPROVED BY MEMBERS OF THE THESIS COMMITTEE:

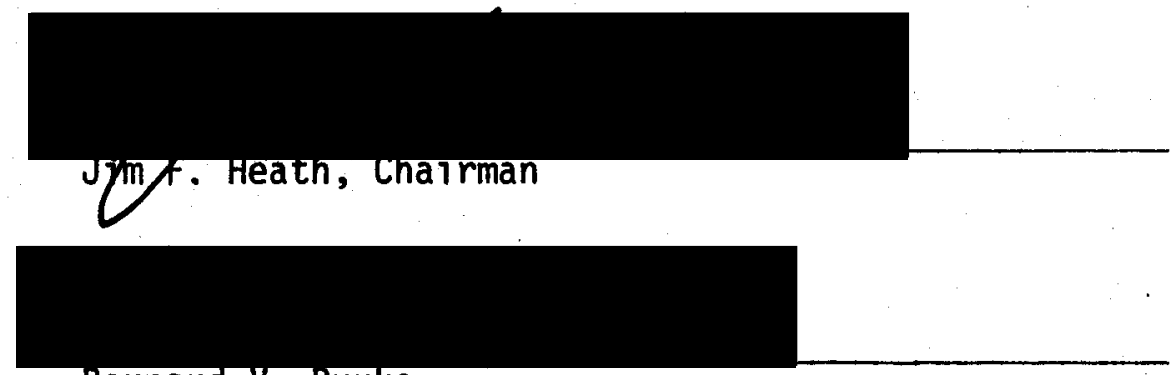

Bernard V. Burke

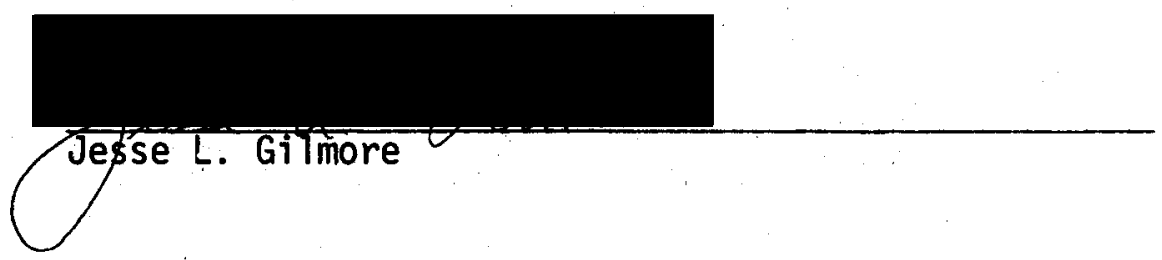

Reviewing the scope and credibility of C. Wright Mills' provocative study, The Power Elite, for a seminar on U. S. in the Sixties prompted my interest in the validity of assessing the historical process by means of the elitist perspective. This coupled with my belief that the New Deal era ushered in a new chapter in the political history of the United States precipitated an investigation of the elitist perspective and how that perspective illuminated the conditions of historical change effected by the New Deal.

To develop this theme of the credibility of the elitist interpretation of history generally and its particular implications for New Deal 
historiography, I undertook a thorough investigation of the works of the writers of the elitist school of thought around the turn of the last century. The central assumption underlying this intellectual discourse is that in any society there is a distinction between those who rule and those who do not. It encompasses all aspects of society, not just in the political sphere which makes for ready analysis and investigation. It has, by narrowing the historical perspective under inquiry, facilitated the understanding of social change by viewing it as the process of the circulation of elites into ruling positions as this circulation is reflective of the transformations taking place within society.

In order to assess the operation of this perspective within democratic societies, and more particularly within the United States, I examined the process of elite rule in the United States. My investigation prompted the conclusion that within the constructs of a procedural democracy which operates via the political vehicles of fixed, competitive elections, rights of political association, and the freedoms of speech and press, elites are at least nominally held in check as to the extent of their rule. Because of this, it is highly improbable that blatant violations by the elite of democratic traditions would occur in an open society claiming democratic techniques of rule. Although the dictates of the procedural democracy in operation in the United States modify the behavior of its elites, they do not undermine the viability of the elites to rule. What has seemed peculiar to the American tradition of elite rule is that the circulation of elites is characterized by a gradual and non-violent process--the process being triggered by the existing elite's ineffectiveness to meet the challenges of the times.

In determining the extent to which elite circulation effected the contours of the New Deal program, I focused on the implications of the 
mobilization of social scientists and intellectuals within the federal government. This inquiry illuminated several factors: 1) that this mobilization was to a large extent the culmination of the federal government's growing reliance on the institutes of social science during the Twenties; 2) that this new mobilization was largely instrumental in the formulation of the New Deal program which established the welfare state; and 3$)$ with the Reorganization Act of 1939, this new mobilization was secured of a permanent place in the federal bureaucracy.

Viewing the New Deal within the parameters of the elitist perspective, one is able to discern the transitional role it played between the political dictates of an earlier era and the political demands of the modern age. The Thirties marked the evolution in the federal government from its traditional role of arbitrator or regulator of the nation's infrastructures to that of guarantor of the social and economic order. The Great Depression had precipitated this demand for the enlarged responsibilities of the federal government, and the New Deal facilitated the transition. Central to this process of change and transition, which characterized the scope of the New Deal, was the circulation into the federal government of a new elite of academics and social science orientated intellectuals. Their impact was significant in terms of the legislation initiated, and enacted, the added dimension of social planning and social research within the federal government, and the restructuring of the administrative network of the federal government with the Reorganization Act of 1939. 
THE CIRCULATION OF ELITES IN TWENTIETH CENTURY AMERICAN HISTORY:

THE NEW DEAL AS A CASE STUDY

by

Diane Theresa Volk

A thesis submitted in partial fulfillment of the requirements for the degree of

MASTER OF ARTS

in HISTORY

Portland State University

1976 
TO THE OFFICE OF GRADUATE STUDIES AND RESEARCH:

The members of the Committee approve the thesis of

Diane Theresa Volk presented Aprịl 26, 1976.

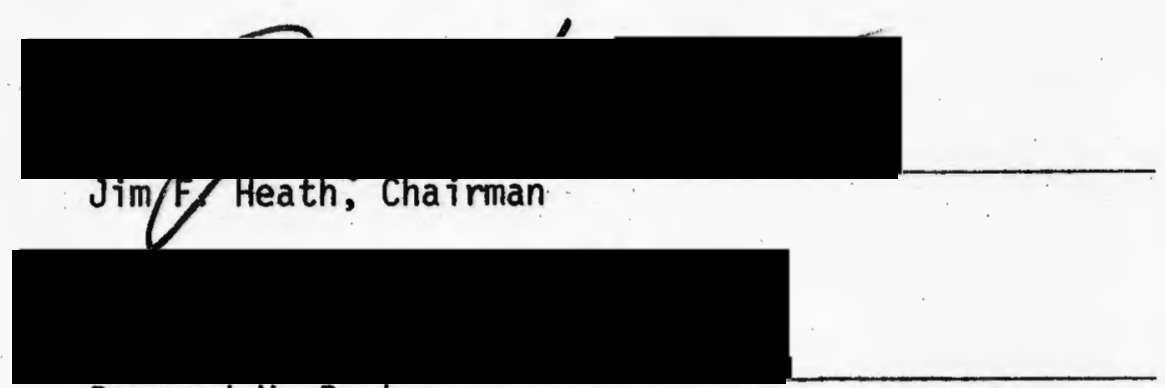

Bernard V. Burke

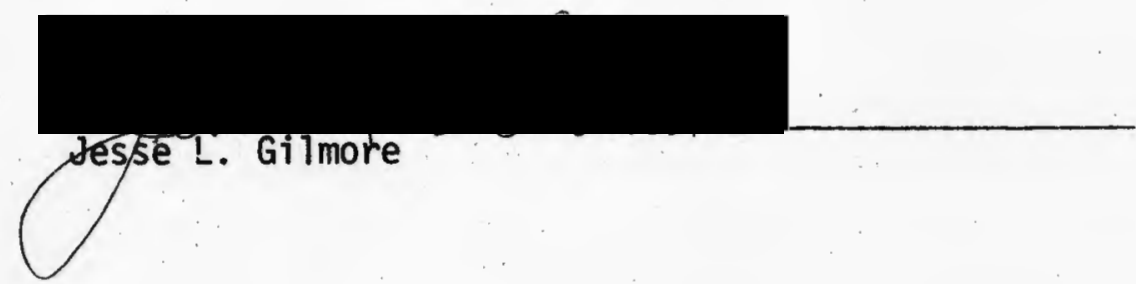

APPROVED:

Michael F. Reardon, head, Department of History

Richard B. Halley, Acting Dean of Gradyate Studies

Apri1 26, 1976 


\section{ACKNOWLEDGMENTS}

My most sincere thanks and deep appreciation for the encouragement and guidance given to me throughout the entire course of researching and writing this thesis go to: Jim F. Heath, Bernard Burke and Jesse Gilmore of the History Department; my colleagues in the History Department's student work room; my parents; and most especially Jim Reeves. 


\section{TABLE OF CONTENTS}

PAGE

ACKNOWLEDGMENTS ............................ CHAPTER

I INTRQDUCTION $\ldots \ldots \ldots \ldots$ I

II ELITE THEORY . . . . . . . . . . . . . 8

II ELITE THEORY AND DEMOCRATIC SOCIETIES ........ 31

IV THE EMERGING COUNTER-ELITE IN THE SOCIAL SCIENCES . . 44

$\checkmark$ THE NEW DEAL AND THE NEW ELITE .......... 68

$\begin{array}{ll}\text { VI THE REORGANIZATION OF THE FEDERAL GOVERNMENT AND THE } & 101\end{array}$

VII CONCIUSION ........................... 119

BIBLIOGRAPHY ........................... 129 
CHAPTER I

INTRODUCTION

Revisionism plays a vital role in any scholarly discipline, especially history. Without the addition and assimilation of new thinking, opposing interpretations, or conflicting ideas, the significance of the academic professions would be greatly diminished by the stagnation of outmoded theories and explanations. On the other hand, unsubstantiated theories and wild guesses or speculations are hardly welcomed, since they tend to undermine the credibility of the disciplines. Nevertheless, the constant questioning of the current"standard" works in light of new data or novel interpretations substantiated by research is the life blood of scholarship.

Interpreting recent history offers a unique challenge to any scholar. At times one's perspective is clouded by presentism and objectivity is lost. But if all subjectivity is subordinated to the goal of strict objectivity, the spirit of the time in question can also be forfeited. This double jeopardy, however, does not completely cripple the viability of historians of the recent past. The study of modern history offers unique advantages not afforded scholars of distant eras. Witnessing the constantly expanding field as new data surfaces, the chronicler of "modern" times must frequently rewrite and redevelop even the most elementary assumptions of his era--thus spending much time within the framework of revisionism. It is here where many of the creative aspects of writing history are realized. 
The first definitive historical work on Franklin Roosevelt's New Deal has yet to be written, because researchers are still anticipating the emergence of additional data to enlarge the historical record. Before such a study is submitted to the profession, I would like to propose for further investigation a largely untapped area within this era-an analysis of the domestic New Deal as shaped by the emergence of a new elite.

Since the publication of C. Wright Mills' The Power Elite in 1956 , there has been much debate in the intellectual community over the aptness or indeed the credibility of Mills' conceptualization of American society. Many social scientists have adopted and adapted his themes of the virtually unchecked power of an elite that directs and molds the political, economic, and military direction of American society in order to reanalyze much, if not all, of the history of the United States. Hindsight allows the scholar the advantage to see how history unfolds, but it is not a tool to set up casual relationships--a tactic employed by many historians to forge extended threads of continuity between periods which provides for a highly monistic view of history. The elitist perspective offers a wide-range of research possibilities, since its basic hypothesis of minority rule ${ }^{2}$ illuminates a condition or state of affairs that may be found in any society at any given time. But it is not a complete theory of history and should not be taken as such:

Although the elite perspective provides insight into historical change, social stability, stagnation, and even decay, it is by no means a complete theory of history. History may have a single ultimate efficient cause, such as class conflict, or more likely, it may be shaped by a variety 
of factors, such as belief systems, biological determinism, technological conditions, heroes in history, and fortuitous circumstances. Elite theory cannot tell us what finally accounts for the movement of history, and probably no general theory ever will. But elite theory is consistent with various perspectives on historical causation and can itself add considerably to our understanding. 3

Given these guidelines, the elitist perspective can enlarge the historical scope of study, but taken in a dogmatic fashion it can also completely distort the historical record. Even Mills, a major proponent of elite studies, warned against such a dogmatic approach to history and the need for scholars to define specifically the elite groups under investigation:

It is not my thesis that for all epochs of human history and in all nations, a creative minority, a ruling class, an omnipotent elite shapes all historical events. Such statements, upon careful examination, usually turn out to be mere tautologies, and even when they are not, they are so entirely general as to be useless. . . If we insist that the elite be defined as a strictly coordinated class that continually and absolutely rules, we are closing off from our view much to what the term more modestly defined might open up to our observation. In short, our definition of the power elite cannot properly contain dogma concerning the degree and kind of power that ruling groups everywhere have. Much less should it permit us to smuggle into our discussion a theory of history. 4

Extreme dogmatic approaches to history via elite theory usually uncover "a conspiracy of an easily located set of villians" the validity of approaching history from an elitist viewpoint. To analyze how shifts in the power structure of society present opportunities for various elites and how they respond to the challenges is not to indict a set of "villians," but rather to attempt to understand how power changes affect society at a given period of time. "Witchhunting" is not the task for historians, and to use the profession for this 
purpose detracts from its standing among the social sciences. Because elite theory is a susceptible target for such a purpose, great care must be taken when utilizing this perspective as a mode of historical inquiry. One of the basic tenets of the elitist perspective is that in all societies rule is executed by a minority, a ruling class. It is not only the pinpointing of this minority that is important for the elaboration of the elitist perspective. With an analysis of the factors that perpetuate the given elite groups-the elite consensus, selection, mobility, and circulation--the historian can piece together more accurately a broad overview of the period under investigation.

The main purpose of this study is to analyze the incorporation of a new political class of social science orientated intellectuals in government service during the New Deal period. Their inclusion exemplified the circulation of a new elite which had its origins in the newly founded institutes of social science during the Twenties.*. As the viability of social science as a means to analyze and resolve the problems of modern society increased throughout the Twenties, the different branches of government began to utilize these "technicians" of social science in various capacities in order to meet the organizational demands of the new industrial age. At first such consultations between the government and the intellectual community were brief and short-lived, but by

*Elite circulation is explained in greater detail in Chapters 2 and 3 , but a brief definition of it is the process whereby elite powerholders are replaced by a new elite reflecting a new elite concensus shaped by social and economic transformations within the system. 
the end of the New Deal a permanent mobilization of academics and social science orientated intellectuals had been established in Washington. This phenomenon, its roots and its implementation into the top-level channels of national policy-making, is the focus of this work.

Because a thorough understanding of the elitist perspective is an integral facet of this proposed study, the following two chapters deal exclusively with elitist thought. Its conceptualization and its modern formulation around the turn of the last century by such scholars as Gaetano Mosca, Vilfredo Pareto, Robert Michels, and others is the subject of Chapter Two. Similarly the focus of Chapter Three deals with the application of elite theory to democratic societies in general and to the United States in particular. This information, although brief, will help to familiarize readers with the major factors and assumptions of elite theory.

An examination of the roots of the new political elite of academics and intellectuals is the primary concern of Chapter Four. The emerging power and viability of this elite is traced to the rise of the institutes of social science during the Twenties which advanced the methodology of social science as well as its application to solving the social disorders of the enlarging industrial society. By the end of the Twenties this newly emerging political elite was recognized and recruited in modest numbers by the federal government to staff various commissions and committees for the gathering of social intelligence needed to formulate national policy. In this manner, this rising political elite made its initial penetration into the thresholds of national decision-making. 
Frankl in Roosevelt, in his attempts to reverse the economic dilemmas of the depression, mobilized this elite in Washington to formulate the program of the New Deal. The wholesale recruitment of this new elite, its influence in writing most of the significant legislation of the New Deal, which both expanded the scope of federal responsibility to the social and economic well-being of the nation and established the welfare positive state, and its adaptability to the political context of the federal bureaucracy comprises the primary focus and analys is of Chapter Five.

An analysis of the reorganization of the executive branch of the federal government during the latter half of the Thirties is the emphasis of Chapter Six. This endeavor, encouraged and implemented by the new elite of academics and intellectuals, is investigated both in terms of the advancement of the efficiency of administration and of the establishment of permanent positions in the channels of national policy-making for this new elite. With the implementation of the Reorganization Act of 1939, the new elite became implanted in the federal government--the cycle of elite circulation complete. Closing remarks and conclusions complete the Seventh and final chapter.

It is hoped that this study of Franklin Roosevelt's New Deal will enlarge the present scope of New Deal history by placing it within the historiography of revisionism which plays a vital role in the expansion of historical understanding. 


\section{ENDNOTES}

ISee G. William Domhoff and Hoyt B. Ballard, C. Wright Mills and the Power Elite (Boston, 1968), for a representative survey of the debate over MiTls' Thesis.

2Elite Theory holds that in all societies rule is carried out by a small minority which constitutes the ruling class. See H. Stuart Hughes, Consciousness and Society (New York, 1958), pp. 250255; James Burnham, The Machiavellians (New York, 1943), pp. 2-8; and Harry K. Girvetz, ed., Democracy and Elitism (New York, 1967), pp. $30-35$. 1973), p. 232.

$3^{3}$ Kenneth Prewitt and Alan Stone, The Ruling Elites (New York,

4C. Wright Mills, The Power Elite (New York, 1956), p. 20.

${ }^{5}$ Ibid., p. 27. 


\section{CHAPTER II}

\section{ELITE THEORY}

The Aristotelian methodology of political classification ${ }^{1}$ dominated to a large degree the political sciences up until the advent of the elite theories of the late nineteenth and early twentieth centuries. $^{2}$ With the formulations of the elitist perspective concerning the nature and structure of ruling classes, the ancient Aristotelian assumption of political classification no longer maintained its almost universal appeal. Whereas Aristotle distinguished differing political systems by separate classifications, the proponents of the elitist school of thought asserted that all forms of government were actually dominated by a select minority: "IIn $\bar{I}$ all societies rule is inevitably exercised by a minority, a ruling class. This is as true under a so-called democracy as under any other form of government." ${ }^{3}$ With the establishment of credibility of this assertion, new avenues of understanding and analysis were opened up to the social scientists of the modern era.

The major advocates of the "Machiavellian" school of thought-Gaetano Mosca, Vilfredo Pareto, and Robert Michels--are not considered "in terms of wide-ranging imagination and a sophisticated understanding of the categories of social thought" ${ }^{15}$ as the key political thinkers of the early twentieth century. Nevertheless the novel and narrow focus of their work gave it an immediate as well as a lasting dialetical 
influence on the intellectual community. In particular these writers formulated in a manifest scientific design "the newly rediscovered political doctrines that Sorel and Spengler enunciated in intentionally provocative fragments, ${ }^{\prime 6}$ and the work Machiavel1i had attempted centuries earlier. Building upon these foundations, the elitists constructed a theoretical framework which eventually included in its scope all social sciences.

The intellectual climate of the late nineteenth and early twentieth centuries also contributed largely to the backgrounds of the elitist writers. The dictates of positivism, which provided the key to the establishment of the modern social sciences, were widely shared and advocated among social and political writers:

A11 were, in varying degrees, animated by the conviction that the study of society could be advanced if its practitioners succeeded in assimilating the spirit and general methods employed in the more "exact" sciences. By means of observation, classification of data, and testing, social phenomena could be made to yield "laws" predicting the future course of events."

This, coupled with the concept of organization which preoccupied theorists of this period, ${ }^{8}$ advanced social inquiry in new directions:

The organizationists looked upon society as an order of functions, a utilitarian construct of integrated activity, a means for focusing human energies in a combined effort. . - Organization also signified a method of social control, a means for imparting order, structure, and regularity to society. ${ }^{9}$

Within this framework of scholarship dominated by a positivist tradition of methodology and a preoccupation with the organizational aspects and potentials of society, the elitist writers fell heir to the Machiavellian tradition. 
Centuries earlier at the beginning of the scientific age, Machiavelli, an Italian political scientist, through the course of several works, namely Discourses on Livy and The Prince, sought to free the study of politics from ethics which had been interdependent from the time of Aristotle and which had dominated Medieval political thought. ${ }^{10}$ In divorcing politics from its ethical base, Machiavelli substituted a scientific method in his analysis of politics for the purposes of attaining an objectivity which is essential to all sciences. In the course of his study, Machiavelli established a methodology which was to bind his writings and theoretical formulations. Concerning this methodology, James Burnham, political theorist, comments:
. . . in the first place, we find that Machiavelli uses language in a cognitive, scientific manner. . . Second, Machiavelli delineates with sufficient clarity the field of politics. . . Third, Machiavelli assembles, and with some measure of system, a large number of facts: facts drawn from his reading in the historical works available to him, from what others, prominent in the politics of his own day, have told him, and from what he himself has observed during his own active political career. . . Fourth, Machiavelli is always attempting to correlate sets of facts into gen- eralization or laws. . . Finally, though this is not strictly part of the logic of scientific method, we feel everywhere in Machiavel1i. . . an intense and dominant passion for the truth. 11

In such a manner Machiavelli defined politics as the struggle for power among members of society. ${ }^{12}$ His intensive methodology resulted in the observation that within society there are two types of "political man"--the "ruler-type" and the "ruled-type". These prototypes of political man became the focal point of his political science which sought to generalize those characteristics peculiar to each type of 
political man and to extend these generalizations into a general hypothesis on the nature of political organization.

The "ruled-type," according to Machiavelli, comprises the great majority, its chief characteristic being political passivity. Unless driven by the most extreme provocation on the part of the rulers or by rare and extraordinary circumstance, the ruled are not interested in power. They want a minimum of security, and a chance to live their own lives and manage their concerns. ${ }^{13}$ In contrast, the characteristics of the "ruler-type" have ambition, drive, and spirit-the qualities which perpetuate rule during difficult times. ${ }^{14}$ War and fighting train the potential rulers, and when once in power, the ruler can then secure his reign on the basis of force. More important than force, however, is fraud which Machiavelli attributes as an indispensable characteristic of the viable "ruler-type." With fraud the ruler can continue in power by manipulating both potential rulers and the ruled. Superceding a 11 these factors as an essential ingredient for lasting rule is skill at adapting to the environment of the times as "neither cruelty nor humaneness, neither rashness nor caution, neither liberality nor avarice avails in the struggle for power unless the times are suited. "15 With these observations of political man, Machiavelli started an unfinished chapter in political science guided by the precepts of the scientific tradition. Lacking the methodology to procure a highly systematic theory transcending the limitations of any one social science, Machiavelli, nevertheless posed questions which eventually formulated a cross-disciplinary 
elitist school of thought among the social sciences of the twentieth century.

Two writers, forshadowing the emergence of the neo-Machiavellian school of thought, Georges Sorel and Oswald Spengler, contributed an array of scholarship to the intellectual community which advanced in fragmentary form conceptualizations later developed by the elite theorists. Georges Sore1, a self-educated French critic of European degeneracy, writing at the turn of the last century, envisioned a society devoid of the false hopes and promises imbued by the successive liberal revolutions since 1789 and the chaos imposed by man's harsh encounter with the industrial age. ${ }^{16}$ The ancient classical world provided Sorel with a source of inspiration for a new schema which would transform the degenerate contemporary society into a renaissance of heroic grandeur. La Ruine du Monde Antique, the product of his study of the ancient world, summarized the general formulations of his schema. He asserted, by means of tracing western civilization through three cyclical ascending and descending phases, that the absence of struggle or conflict in society was the key causal factor in decline. ${ }^{17}$ According to Sorel, the absence of struggle or conflict in society presupposes a decline in decisiveness, a loss of civic duty, the roots of widespread degeneration which is "accelerated by the questioning of rationalism; a malady of reflection and self-analysis paralyzes the will to action. "18 What was needed in contemporary society, then, was the source of conflict with which men could identify and by which the age could be sustained. The proper regulation of this conflict, theorized Sorel in his later works, especially Reflections on Violence, 
would bring back a heroic age of grandeur. This regulation of conflict would be achieved by the utilization of the political myth:

Experience shows that the framing of a future, in some indeterminate time, may, when it is done in a certain way, be very effective, and have few inconveniences; this happens when the anticipations of the future take the form of those myths, which enclose with them, all the strongest inclinations of a people, of a party or of a class, inclinations which recur to the mind with the insistence of instincts in all the circumstances of life...

What was implied was the creation of an elite class whereby the leaders of society were characterized by their ability to "captivate and galvanize" the masses via the myth. "The useful lie serves to direct men into action and at the time create the basis of leadership... Sorel's was an elitism based neither on social status nor intellectual achievements, but on the ability to sustain and arouse passions." 20 Though Sorel exposed these ideas of non-logical action and mythmanipulation, he lacked the skill to translate his ideas into a coherent theory. "His 'diremptions' and 'myths' offered the elements at least of a more coherent theory. But he was unable to fit the pieces together."21 The opposite was the case for Oswald Spengler whose extreme tendencies pushed the logic of his conceptualizations to their furthermost limits. ${ }^{22}$

Spengler, a German speculative historian at the turn of the last century, asserted throughout the course of his work, which culminated with The Decline of the West, that definite laws of growth determine history and that consequently history is predictable. ${ }^{23}$ This stance, based on the notion of cycles, appeared as a recurrent theme in the 
scholarhsip of this period, but never in such a dogmatic fashion as

to formulate such a theory of history. As one critic wrote:

The Decline of the West marked the full formulation of a cyclical theory of historical change and a comparative approach to the study of culture which had gradually been establishing themselves among the implicit presuppositions of early twentieth-century social thought. The notion of cycles had underlain Sorel's respect for the values of a simpler age and his skepticism about the "illusions of progress." It had figured more explicitly in Pareto's hypothesis of an alteration between periods in which "persistence of aggregrates" was dominant and those in which the instinct for combinations" held sway. ${ }^{24}$

Though cyclical theory found its way into the formulation of elitist theory, it provided merely a factor within the overall framework and never a determinist overview of the course of all human history. Such was never the work of the elite theorists whose utilization of the concepts of social change and continuity within the context of elitism would be for the purpose of expanding historical understanding, not to delimit it further with a theory of history. Nevertheless, in modest degree, the Spenglerian influence has become an integral ingredient in elitist thought.

A trio of neo-Machiavellians, Gaetano Mosca, Robert Michels, and Vilfredo Pareto, shaped these fragments of intellectual thought into a theoretical formulation of elitism.

As speculative sociologists Pareto and Mosca and Michels were alike Machiavellians in their insistence on the sharp separation between rulers and ruled, on the necessary role of force and fraud in government, and on the inevitable degeneration of all political groups and institutions. With these pessimistic doctrines, they coupled in only apparent disharmony--an equally Machiavellian longing for freedom. 25

It is through these theorists primarily that contemporary social science has derived the notion of political and social elites. And within the 
common agreement on the theory of governing minorities, each of these three thinkers has placed his emphasis on different aspects of the formulation which have expanded the scope and direction of this intellectual inquiry.

Gaetano Mosca, an Italian political scientist whose work bridged the nineteenth and twentieth centuries, first formulated the theory of a political ruling class in a work entitled Teorica dei governi. His primary concern was the study of the operation of governing bodies and the behavior of political groups within society. From this study, which was more fully exposed in The Ruling Class, Mosca concluded that the political process was manipulated by "narrow and self-perpetuating cliques." His scope of study was characteristically political and he did little more than imply that the concept of self-perpetuating minorities of rulers could apply to society as a whole. "Yet below the surface of political reasoning, Mosca suggested a wider social application." 26 In his discussion of the composition and character of the ruling class, Mosca found that various sections of the ruling class expressed or represented social forces which continually varied in number and importance. He observes:

As civilization grows, the number of moral and material influences which are capable of becoming social forces increases. For example, property in money, as the fruit of industry and commerce, comes into being alongs ide of real property. Education progresses. Occupations based on scientific knowledge gain in importance.

Factors, such as these mentioned by Mosca, can function as social forces if society is organized in terms of them. Given this observation, Mosca asserted that the relations of a ruling class to society need not be 
at all arbitrary. In fact, to survive, a ruling class must be flexible enough to meet the challenge of new and powerful social forces. This growth of new social forces as well as the decline of old forces accounts for the constant process of change and dislocation in the ruling class. ${ }^{28}$ This notion forshadows Pareto's conceptualization of the "circulation of elites" which underlies his sociology and which has emerged as one of the most important formulations of the elite school.

Borrowing from Sorel, Mosca theorized that the ruling class express its role and position through a political formula, a myth. The purpose of such a formula is to legitimize the rule and the structure of society over which a ruling class governs. Mosca notes:

According to the level of civilization in the peoples among whom they are current, the various political formulas may be based either upon supernatural belief or upon concepts which, if they do not correspond to positive realities, at least appear to be rational. We shall not say that they correspond in either case to scientific truths. . . And yet that does not mean that political formulas are mere quackeries aptly invented to trick the masses into obedience. . . The truth is that they answer a real need in man's social nature; and this need, so universally felt, of governing and knowing that one is governed not on the basis of mere material or intellectual force, but on the basis of a moral principle, has beyond any doubt a practical and real importance. 29

In order for political formulas to be long-lived, Mosca observed from history, their essential ingredient must be integrity in order to withstand changes in the social structure as well as to advance support from the masses. "It is perhaps for this reason, halfconsciously understood, that all strong and long-lived societies have cherished their traditions, even. . .when. . .these traditions have little relation to the fact." 30 
Extending his model of a ruling elite to embody all types of governing entities, Mosca cites two principles--"autocratic and liberal"-which serve as the development laws of ruling classes and which distinguish types of rule among the various ruling elites: "In any form of political organization, authority is either transmitted from above downward in the political or social scale / The autocratic principle $\overline{7}$, or below upward / the liberal principle $\bar{l} ., " 31$ Neither of these principles contradicts his main assertion that society is divided into a ruling minority and ruled majority since the principles relate solely to the selection of leadership within the ruling class. Though the mode of entry to the ruling circles changes with the type of principle employed by a given society, the formation of closed cliques at the top remains a constant; the manner of formation is the only variable. Under this line of reasoning, Mosca further explains his two development laws of ruling elites:

In order to reach a high station in an autocracy, it is sufficient to have the support of one or more persons. . . In liberal systems one has to steer the inclinations of at least the whole second stratum of the ruling class, which, if it does not in itself constitute the electorate, at least supplies the general staff of leaders who form the opinions and determines the conduct of the electing body. 32

Distinguishing selection of leadership from recruitment into the ruling classes, Mosca uses the terms "aristocratic" and "democratic" tendencies, referring to the sources from which new membership to the ruling classes are drawn. Replenishment of the ruling class with members from the lower classes defines the democratic tendency whereas replenishment of the ranks from descendents of the incumbents of power marks the aristocratic tendency. ${ }^{33}$ Mosca discovered that both tendencies 
are always operative within every society, 34 since the presence of an elite transcends the guiding traditions or slogans of a particular society. Thus the recruitment process becomes an independent factor utilized by the elite for perpetuation. Within the larger dictates of the political myth or formula which is the ultimate behavior modifier of the elite body, elite groups utilize various methods of recruitment embodying both tendencies on a flexible basis attuned to the times and circumstances involved.

These main concerns of Gaetano Mosca's works on elitism--the concepts of a ruling class, its political application guided by the principles of a political formula or myth, and the tendencies of elite recruitment--advanced to a much more theoretical ground than had the works of Sorel and Spengler, but Mosca's typically political referent prevented him from generalizing his statement on elites to other spheres or spectrums within society. "It was left for Michels to extend Mosca's theories to the mass organizations" 35 and for Pareto to implement the theory of elites as the major factor in his general hypothesis on the workings of society.

In his study entitled Political Parties, Robert Michels, a French contemporary of Mosca, attempted to uncover the general laws or tendencies of organization which he considered an integral aspect of society as well as a universal feature of human life. Drawing much of his data from the experiences of the German Social Democratic Party, Michels observed that when an organization expanded and its aims had a certain "scope and importance," its organizational affairs became very 
complex and demanded the execution of innumberable bureaucratic details to stay functionary. But by the application of the principle of division of labor, the demands of organization are met, creating within the organization a minority of defacto leadership:

Certain individuals specialize in the tasks peculiar to the organization and its operational 1 ife; they devote all or a considerable portion of their time and intelligence to the organization; they perfect themselves in the organizational duties. . Except through such a division of labor and specialization, there is no way for the organization to
continue in active existence. 36 .

Because of this principle inherent in the existence of any large-scale organization, a class of leadership clearly distinguished from the masses emerges. Michels investigates this further in an attempt to determine who rules whom---the mass or the leadership? Michels discovered several advantages on the side of leadership through the course of his investigation. The customary right to hold office, Michels notes, has replaced the birth-right in nearly all large scale organizations. 37 This may superficially signify an equal opportunity for all, but in practice, the mere fact that an individual has held the office in the past is thought by him and by the members to give him a moral claim on it, or on some other leadership post in the organization. Significantly, once dues of leadership are paid, the organization takes care of its own. Even more fundamental than the right to office, Michels found, was the psychological dependency felt by the masses for leadership. As Machiavelli had noted centuries earlier, Michels rediscovered the same tendencies in modern man:

Though it grumbles occasionally, the majority is really delighted to find persons who will take the trouble to look after its affairs. In the mass, and even in the 
organized mass of the labor parties, there is an immense need for direction and guidance. The need is accompanied by a genuine cult for the leaders who are regarded as heroes. 38

Other qualities as well secure for the leadership a dominating stronghold over the vast majority. These qualities, which could be considered as specific qualities of leadership, do not necessarily characterize every leader but represent the leadership generally. Among them are force of will, a wider extent of knowledge which impresses the ranks, the force of ideas which rouses the masses, a self-sufficiency which inspires the vast majority, and in very rare cases a goodness of heart which reignites religious feelings. ${ }^{39}$ In short, the leadership as a whole or as a group are indispensable to every important organization, and it is this indispensability that is their strongest lever to perpetuation and control of the decisionmaking process. According to Michels, the necessary outcome of this indispensability to the masses is that the power of the leadership is consolidated in an organized sub-group independent of mass action and control. Thus the leadership as an organized body has a distinct and powerful advantage over the ruled majority in every organization. 40

Though the organized leadership maintains the advantage over the masses in the political power play, leaders are at times ousted. Michels recognized this possibility and demonstrated that such an apparent reversal in the power struggle is completely in accordance with his general theory of the supremacy of leadership. Such instances usually occur under two circumstances:

In the first place, if a division occurs among leaders, one section or both is forced to seek help from the masses of the 
membership, and is able to organize their strength. The opposition leadership is sometimes successful in eliminating the old leadership. Second, new leaders may, and do, arise as it were spontaneously out of the masses. If the existing leadership is unable or unwilling to crush or assimilate these "outside" leaders, then it may be overthrown. ${ }^{41}$

Seemingly the leadership loses power, but Michels asserts that what in fact happens is only the substitution of one leadership for another and that the reality of leadership control over the masses prevails. ${ }^{42}$ But this opposition, whatever its stance, is the strongest and only firm check on the autocratic tendencies of the leaders. In this way the behavior of the leadership is modified relative to the strength of organized opposition.

No organization can dare dispense with leadership, because anarchy would result making certain the demise of the organization. Consequently leadership remains along with the autocratic tendencies that help perpetuate the ruling elite. "The autocratic tendencies are neither arbitrary nor accidental nor temporary, but inherent in the nature of organization." 43 This "iron law of oligarchy," which Michels' theorized would hold true for all social movements and all forms of society is the end result of his study. What he termed the "iron law of oligarchy" was the codification of the conviction that political organizations "through the internal necessities of discipline and administrative continuity inevitably became closed and self-perpetuating oligarchies." 44 This being the case it is left for the masses through active and organized opposition to modify the behavior of these inevitable oligarchy of organizations. But modification, and not control, typifies the extent of mass power. 
This model, constructed by Robert Michels as an extension of the groundwork previously formulated by Gaetano Mosca in his analys is of the political elite, serves to point out that organization, when once it became an influential factor in the running of "influential" affairs, presupposes the existence of a leadership which not only controls the non-leadership elements of the organization, but itself becomes a closed self-perpetuating organ of rule. Michels' work advanced elitist thought beyond the political arena (though it could be argued that all large organizations are political in character) to that of society as a whole.

Another Machiavellian, Vilfredo Pareto, a French Italian national who spent his productive academic life in Geneva, relegated the study of elites to a singular element in a sociology based on the study of non-logical action. In the last analysis, however, Pareto made a lasting contribution to the extension of elite theory which persisted in an underlying fashion throughout the intricacies of his weighty discourse and which emerged bascially unscathed from the methodological problems which befell his general tract on society. 45

Alone among his elite theorist predecessors, Vilfredo Pareto "went beyond the facts of political manipulation which they all agreed, to attempt a definition of those basic human impulses that offered the raw material for mass leadership." 46 In his treatise, Mind and Society, Pareto distinguishes between logical and non-logical conduct which is the key to his general schema on the workings of society:

A man's conduct (that is, human action) is "logical" under the following circumstances: when his action is motivated by a deliberately held goal or purpose; when that goal is possible; 
When the steps or means he takes to reach the goal are in fact appropriate for reaching it. . . If however, any one or more of the conditions for logical conduct are not present, then the actions are non-logical. 47

Drawing from Sorel's preliminary work on non-logical conduct, ${ }^{48}$ Pareto undertook an exhaustive study of human conduct throughout the course of history to determine to what extent non-logical conduct had a bearing on the "social equilibrium." 49 His evidence supported his contention that what happens to society is only remotely influenced by the rational goals of men, and that the delicate balance of the social equilibirum is primarily effected by non-logical action. The evidence is too vast to review in these pages, but there are certain types of human activities that significantly relate to social and political circumstances which Pareto examines that warrant some critical examination.

Social development correlates directly to such factors as climate and geography as well as to biological and physical characteristics in general. Such influences cannot be considered as logically motivated. Here the influence to social development is remote, but in other areas where the influence is not as remote, the motivation still stands as non-logical by Pareto's definition. For example, social goals, purposes, schemas, etc. of modern man are usually verbalized in documents, programs, laws, slogans, and declarations. In most cases the vagueness and ambiguity of the language presupposes the non-logical motivation involved. As one scholar of elitism explains:

The point is not that these slogans, ideals, or programs, and declarations do not influence action. Under certain circumstances they undoubtedly do, and tremendously. But they are not and cannot be part of logical or rational 
action. I am not taking logical steps in pursuit of

a goal if the presumed goal is nothing definite. 50

Even if the goal were definite, the subsequent activity usually nullifies the effects of the objectivity of that goal. 51 Such was the legacy Pareto derived from history, and with it he formulated his "celebrated theory of 'residues' and 'derivations."

From his discussion of non-logical conduct in which he asserted the primacy of non-logical motivation in relations to social and political change, Pareto proceeds to focus directly on the types of non-logical conduct which comprise such action. He characterizes the two types of non-logical action as "residues" and "derivations" which one commentator describes:

In this schema, the residues represented what was unvarying, or at least what changed only very slowly in human conduct, the derivations the constantly varying explanations and rationalizations of such behavior. 52

of the six residual categories Pareto named, all tended to fall into two main categories or groupings: "(1) 'combinations,' the tendencies to change, newness, manipulations, speculations, upsets, progress; and (2) 'group persistences,' the tendencies to inertia, resistance to social change, social solidarity, conversion, conformity." 53 Along with these constants in history are the variable factors, the manifestations of residues which Pareto defines as derivations. They include the categories of "assertion, authority, accords with sentiment or principles and verbal proofs." 54 Pareto gives little credit for the role of the derivations in determining social change, and concludes that an alteration in the residues in the last analysis changes the status quo. This is but a more generalized form of the theory of the political formula as espoused 
by Mosca and Sorel. In Pareto's language, a derivation is only a rationalization of a status quo, not a primary element in the determination of social development or change. Though derivations cannot be disregarded as unimportant, their importance lies in their relationship to the residues they represent, not in themselves.

Though Pareto's extensive work suffered from his strict adherence to the positivist creed, ${ }^{55}$ his sociology nevertheless contributed largely to elitist thought when, in the final pages of his massive treatise, Mind and Society, he applied his theories of "residues and derivations" to the course of elites in history, the theory of which was in basic agreement with his neo-Machiavellian counterparts.

The assessment of how much of each residue characterized the successive elites in history--and how the contradictory attitude manifested itself either through the progressive infusion of new elements into an old ruling class or through violent overthrow of one elite by another--this estimate of the "social equilibrium" called forth Pareto's most pungent and telling commentary. 56

Giving his general theories a practical application, so to speak, Pareto formulated a theory of social change tied to "elite circulation." Like the other neo-Machiavellians, Pareto held that the character of society is the character of its elite and that in the last analysis the accomplishments of this elite are the accomplishments of society. Thus the social equilibrium is determined by changes static or dynamic within the elite echelons of society. ${ }^{57}$ In terms of Pareto's concentration on the relationship of residues to the determination of the social equilibrium, his concept of elite circulation can be explained as an interplay between the residue of "combination" and the residue of "broup persistence" among elite personnel. If fundamental changes 
redefine the social equilibrium, then it is only because the character of the composition of the elites has altered with either a gradual infusion of new personnel reflecting residual opposition or the complete overthrowing of the old-guard altogether. In either case, social change has taken place, not because of a new rationalization or derivation, but because of the altered residual supremacy among the elite. In this conceptualization of elite circulation, the "lion and fox" metaphor of Machiavelli's writings becomes a sophisticated and exemplary theory of social change which, though clarified by its political context, has essentially umlimited application within all sectors of power concentration in society. Going beyond the political scope of Mosca and delving deeper into human conduct than either Sorel or Michels, Pareto's scholarship contributed a necessary link in the formation of modern social thought. 58

From Machiavelli's "ruler-type" to Sorel's "heroes," Mosca's "ruling class," Michel's "leadership oligarchy," and Pareto's "elites" has emerged a school of thought pursuing the source and perpetuation of power strongholds in society and their relation with the non-powerful members of society--the masses. As seen, the central assumption underlying this intellectual discourse is that in any society there is a distinction between those who rule and those who do not. It encompasses all aspects of society, not just in the political sphere which makes for ready analysis and investigation. The theory of elites makes no pretense to being a theory of all historical change, but rather a means or method to enhance historical understanding regarding social, economic, and political change. It has, by narrowing the historical perspective under inquiry, facilitated the understanding of social change in the 
complex interdependent fashion that it entails in the analysis of any society. As two theorists conclude:

Elite theory pinpoints the central. . actors. It does not tell us how much power they have with respect to any given social policy, and it does not tell us what social goals they will pursue. . Like any social theory there are limits to what the elite perspective can accomplish, and these limits may well preclude its usefuliness in analyzing many social processes. Indeed, one should be wary of any theory whtch seeks to explain too much. What elite theory does explajin entitles it to the highest standing in social sciences. 59 


\section{ENDNOTES}

1Aristotle, Politics (New York, 1943, translated by Benjamin Jowett), pp. 36-37. In these pages of Politics, Aristotle classifies three types of political systems with their opposite forms: monarchy, tyranny; aristocracy, oligarchy; constitutional government, democracy.

2 Kenneth Prewitt and Alan Stone, The Ruling Elites (New York, 1973), pp. 3-4. p. 31 .

3Harry K. Girvetz, ed., Democracy and Elitism (New York, 1967),

${ }^{4}$ This term is given to elite theorists in James Burnham, The Machiavellians (New York, 1943), p. 2. p. 250 .

${ }^{5}$. Stuart Hughes, Consciousness and Society (New York, 1958),

${ }^{6}$ Ibid., p. 250.

7 Sheldon S. Wolin, Politics and Vision (Boston, 1960), p. 358.

8 Ibid., pp. 357-368.

${ }^{9}$ Ibid., p. 364 .

10Burnham, The Machiavellians, pp. 29-30 and James H. Meisel, The Myth of the Ruling Class (Ann Arbor, 1958), pp. 263-285.

11 Burnham, The Machiavellians, pp. 40-47.

12 Niccolo Machiavelli, The Prince (New York, 1950, translasted and revised by Luigi Ricci and E. R. P. Vincent), pp. 35-36.

13Niccolo Machiavel1i, The Discourses (New York, 1950, translasted by Christian E. Detmold), pp. T6T-T62.

14 Machiavel1i, The Prince, pp. 53-66.

15 Burnham, The Machiavellians, p. 60 and Machiavel1i, The Discourses, p. 409.

1.6Georges Sorel, Reflections on Violence (Glencoe, I11inois, 1950 , translated by T. E. Hume and J. Roth), pp. 78-89.

17Neal Wood, "Some Reflections on Sorel and Machiavelli," Political Science Quarterly, LXXXIII (1968), p. 79. 
18 Ibid., p. 81.

${ }^{19}$ Sorel, Reflections on Violence, p. 142.

20 Irving Louis Horowitz, Radicalism and the Revolt Against Reason (New York, 1961), p. 136.

${ }^{21}$ Hughes, Consciousness and Society, p. 182.

22 Ibid., p. 376.

$23 \mathrm{H}$. Stuart Hughes, Oswald Spengler: A Critical Estimate

(New York, 1952), pp. 20-28.

24 Hughes, Consciousness and Society, pp. 375-376.

${ }^{25}$ Ibid., pp. 253-254.

${ }^{26}$ Ibid. p. 255. See also H. Stuart Hughes, "Gaetano Mosca and the Political Lessons of History" in James H. Meisel, ed., Pareto and Mosca, (Englewood Cliffs, New Jersey, 1965), pp. 141-160.

27 Gaetano Mosca, The Ruling Class (New York, 1939, translated and revised by Hannah D. Hahn and Arthur Livingston), pp. 144-145.

28 Burnham, The Machiavellians, p. 98.

${ }^{29}$ Mosca, The Ruling Class, p. 71.

30 Burnham, The Machiavellians, p. 100.

${ }^{31}$ Mosca, The Ruling Class, p. 394.

32 Ibid. , p. 410.

33 Ibid. , p. 395.

34 Ibid., p. 419. See also Burnham, The Machiavellians, p. 105 for a discussion of examples.

35 Hughes, Consciousness and Society, p. 256.

36 Burnham, The Machiavellians, p. 144.

${ }^{37}$ Robert Michels, Political Parties (New York, 1962) translated by Edenand Cedar Paul), pp. 81-84.

$38_{\text {Ibid. , p. } 88 .}$

${ }^{39}$ Ibid., pp. 88-99.

40 Ibid. , pp. $70-77$. 
41 Burnham, The Machiavellians, p. 158 . This is a condensed version of Michels' analysis in Michels, Political Parties, pp. 172-187.

42Michels, Political Parties, p. 187.

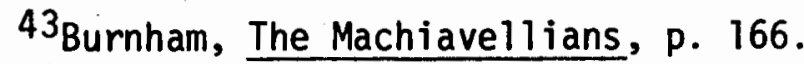

44Hughes, Consciousness and Society, p. 256.

${ }^{45}$ Ibid., pp. 262-264.

46 Ibid., p. 257.

47 Burnham, The Machiavellians, pp. 172-173. This is a clarification of Vilfredo Pareto, The Mind and Society (4 vols., New York, 1935, translated by Andrew Bongiorno and Arthur Livingston), I, paragraphs 150-153.

${ }^{48}$ Hughes, Consciousness and Society, p. 250.

${ }^{49}$ By social equilibrium, Pareto is referring to the political/ social balance of a given society. See Pareto, The Mind and Society, IV, paragraphs 2067-2078. For an analysis of this term see N. S. Timasheff, "The Social System, Structure and Dynamics," in James $H$. Meise1, ed., Pareto and Mosca, pp. 63-68.

${ }^{50}$ Burnham, The Machiavellians, p. 177.

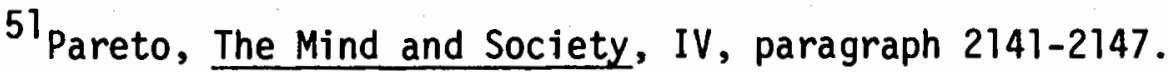

52 Hughes, Consciousness and Society, p. 257--a condensed form of Pareto definitions from Pareto, The Mind and Society, I paragraphs $119,163-291$.

53 Burnham, The Machiavellians, p. 188. From Pareto, The Mind and Society, II, paragraphs 867-1396ff.

54 pareto, The Mind and Society, III, paragraphs 1415-1419.

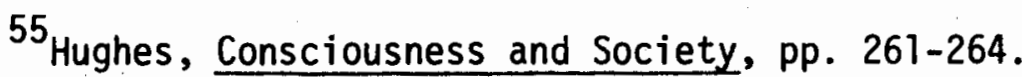

${ }^{56}$ Ibid. p. 267.

57 Pareto, The Mind and Society, IV, paragraphs 2477-2485.

58 Frank Borkenan, "A Manifesto of Our Time," in James H. Meise1, ed., Pareto and Mosca, pp. 109-114.

59 Prewitt and Stone, The Ruling Elites, pp. 236-237. 


\section{CHAPTER III}

\section{ELITE THEORY AND DEMOCRATIC SOCIETIES}

Elitist theory dictates that the presence of an elite group of rulers is neither bound nor limited to any singular type of political structure as elites rule in every society. Although this concept is inherent to elitist theory, the seeming nature and structure of many political entities belies the very existence of elites. Democracies present a case in point. ${ }^{1}$

Democracy as an expression or definition implies the ultimate in political freedom ${ }^{2}$ as the term democracy is usually synonymous with "self-government" or "government by the people." In such a society the establishment of an elite ruling class would be an anathema to the system as well as a contradiction to the tenets of democracy which include popular participation in the decisions that direct the lives of individuals in society, government by majority rule where minorities share the freedoms of press, assembly, and petition, and a commitment to the preservation of the values of life, liberty, and property as well as equal opportunity for all citizens. ${ }^{3}$ This conclusion is, however, clearly premature when placed within the confines of the elitist perspective:

The theory of democracy as self-government must. . .be understood as a myth, formula, or derivation. It does not correspond to any actual or possible social reality. . . . It does not, however follow that the theory of democracy is without any influence on the social structure. . . The ruling minority always seeks to justify and legitimize its 
rule in part through a formula, without which the social structure would disintegrate. The positive significance of democratic theory is as a political formula of this kind. 4

Democracy does not technically mean "self-government " or "government by the people," but it does constitute a unique mechanism of rule whereby the peculiar institutions of suffrage and political liberties modify the political character of the state as well as the behavior of its elites.

Given this perspective of rule, democracy and elitism do not represent two mutualiy exclusive states of affairs, but rather interdependent factors in which elitism corresponds to the general category shaped by the specific conditions implied by the meaning of democracy. Granting the validity of this assumption, the pejorative aura surrounding the term elitism as contrasted with the positive implications of the term democracy provides for another unwarranted problem in this analysis. Elitism connotes subjection, democracy freedom. However "the scholar' cannot be...choosy. He uses words for their descriptive rather than emotional content. ${ }^{5}$ Significantly, though the word elite may evoke negative emotions, it is actually a neutral descriptive term illustrating political realities in society. Democracy offers a political rationale acceptable to certain societies in which both the elites and masses share the stakes involved for the continuation of the social system. But ultimately in any system, the responsibility for stability lies in the hands of the rulers--the elites who, "with few exceptions, have a special stake in the continuation of the system in which their privilege rests. " 6 Imposing the conditions of democracy on the elitist model captures the essence of "the irony of democracy:" 
Democracy is government "by the people," but responsibility for the survival of democracy rests on the shoulders

of the elites. This is the irony of democracy: Elites must govern wisely if government "by the people" is to survive."

Whether it be ironic or not, the traditions of democracy are nurtured by those elites whose existence depends upon the continuation of democratic principles in the system.

In the United States, the principles of democracy have been espoused, propagandized, and seemingly adhered to since the times of the "founding fathers"--the creators of the Constitution. Whether or not the United States is in effect a democracy is not a question to be examined here. But for an examination of the general structure of elitism in America, it is of central importance to discuss how the United States' unique political structure has shaped the nature of its elite recruitment, circulation, and accountability--those factors which determine elite viability and perpetuation.

The amount of power in the hands of any elite group is a matter for investigation, not definition. Therefore, in studying elites in the United States, no attempt is made to label these groups as allpowerful or completely cohesive. For example, the political elite of the United States includes leaders of the political party temporarily out of power as well as persons aspiring to top positions in the political economy who do not necessarily share the views of all the incumbents in power. What is assumed is the presence of elites within the social system and the implications that lie therein:

Elitisin asserts that society is divided into the few who have power and the many who do not. According to elite theory, elites-not masses--allocate values for society. Elites are not typical of the masses in backgrounds or attitudes. Elites share a consensus on behalf of the basic values 
of the system, and public policy reflects prevailing values of elites rather than demands of the masses. Elitism also asserts that changes in public policy are incremental rather than revolutionary, and that movement of non-elites into elite positions is slow and limited only to non-elites who have accepted elite values. Finally elitism asserts that elites influence masses more than masses influence elites. 8

Within the framework of this perspective, certain descriptive patterns of American political elites emerge.

The political history of the United States has been consistent with elitist theory. ${ }^{9}$ The ruling American elite has assimilated diverse groups such as Federalists, Jeffersonians, Industrialists, Liberals, and Minorities (such as Blacks and women) without any significant break in the continuity of the core values and traditions in the American political and economic system as established by the Constitution of 1787 which in itself is a reflection of its framers-a group of wealthy, talented, and educated men representative of powerful political and economic interests. The opposition to the ratification of the Constitution, more significantly typified by the AntiFederalists, who were of the same wealthy background as the Federalist contingent, in the last analysis supported the execution of the Constitution when ratified. Although this demonstrates dissensus within the economic and political elite during the early years of the nation, it also points out that the Anti-Federalists rallied behind the federal government when the circumstances demanded it. Certainly this continuity of elite consensus does not characterize the whole of American history, the Civil War and the political and economic breakdown following the Great Depression of the 1930's being two blatant 
examples of elite conflict during critical periods of American history. Closer examination of these periods reveals that the turning point for renewed elite consensus occured as the reorganized elite "took /the situation $\bar{T}$ into account and either repress_ed], assuage/dT through symbolic benefits, or assuage/d through substantive benefits intended to appease the aggrieved group." 10 The Emancipation Proclamation, a largely military and political manuever on Lincoln's part to preserve the nation, and the establishment of the welfare state by Franklin Roosevelt fit directly into this elitist perspective. Political conflict in American history has involved a very narrow range of issues because of the solidarity of its elites and the loose principles of the Constitution which both bind and guide them.

One of the greatest contributions of the democratic revolution was to shift the patterns and cycles of the elite recruitment from the qualifying factors of birth and bloodline to those of talent, achievement, and accomplishment. "1 This is not to suggest that the elite recruitment process in the United States has been open to all (BLacks and women, for example, were excluded), but the process has involved a much more complex model than that of simple biological reproduction and heredity.

Opportunity for entry into the elite circles in the United States has not been arbitrarily determined by any one factor, but the chances for elite recruitment when distributed over the entire population have not fallen equally. Factors of family background, social status, religious affliation, education, sex, race, and political connections 
have and continue to contribute favorably to the advantage of some as well as to the disadvantage of others. ${ }^{12}$ Though these factors can facilitate vertical movement into elite channels, they can never guarantee it as the motivations of ambition or success as well as the very real possibility of a changing political climate could well alter the patterns of recruitment.

In a capitalist nation such as the United States, wealth has determined social status, and those possessing a disproportionate share of the nation's capital have assumed that same disproportionate share of power. That a class bias based primarily on wealth remains a decisive, if not a fixed, factor in the recruitment to the top positions of the political economy is evidence by the assertion of elite theorists that the wealthiest one-fifth of all American families have held about nine out of every ten elite positions on the federal level in the political economy with the next wealthiest controlling the remainder, save for a few token positions scattered among the rest. ${ }^{13}$ The reinforcement of this social phenomenon whereby wealth provides the necessary criteria for elevation in the hierarchy of power is reflected in the old bourgeois dictum "that power and status should be congruent in society." 14 Several infrastructures within the social system continue to reinforce this power/status ratio. Self-esteem characterizes the nature of wealthy, influential families. Patricians act as if they should be issuing orders, asserting themselves to legitimize their status in society. Patterns of self-assertion and self-esteem do not necessarily correspond perfectly with social status, but the relationship has tested positive and rather strong. 15 This 
legitimization of political authority for the socially prestigious has been further cemented by the electorate which weighs the candidates past achievements as an indicator of future success. Weal th has had the tendency to demonstrate achievement whether it be acquired or inherited:

If the wealthy and presitgious of society have a platform on which to display their achievements, they have additional advantage as well. They are successful in those activities that correspond closely to what is most esteemed in society. The head of a giant corporation or the talented lawyer, much more than the successful entertainer, intellectual or athlete, claims that that in which he excels is critical to the well-being of the whole of society. 16

Though it is questionable to some whether the majority of elected politicians could be considered elite personnel, ${ }^{17}$ these positions have trained and groomed selected individuals for further advancement. More important than the electorate in the recruitment process have been the elites themselves who have hand-picked replacements. They have tended to select men of similar mind set, background, and status as precautionary measures to ensure the perpetuation of similar rule. That the weal thy classes have functioned as a pool for elite recruitment has been a constant phenomenon throughout American history.

Wealth and family connections have facilitated elite recruitment, but in order to arrive at the top, political beliefs must fall within the parameters of acceptable political and economic orientation. These parameters eliminate the possibility of radical viewpoints from the far left and far right, but the end result is far from total consensus. Within the elite, wide-ranging view points have been kept alive by "party" politics which is as much an integral part of the business and military elites as the elites of the political sphere. 
Codes of conduct, and the adherence to the American traditions of private enterprise and a self-restraining government have held the elites in check in the making of essentially conservative political/ economic decisions in a protectionist light.

The process and nature of elite circulation characterizes the manner in which the transferral of power maintains stability within an elitist system. The circulation of elites is defined by the process whereby the ability to govern and the powers of government lie in the same hands as well as that process which allows for the expression of social interests withn the elite circles. ${ }^{18}$ If the upward or downward channels of mobility are blocked, the process deteriorates and social stability is jeopardized. Elite circulation can take place in either of two ways: slowly through assimilation and recruitment or suddenly through rebellion or revolution. The American experience has been one of the latter in which groups fostering broad social interests have organized and upon maturity and acceptance within the system shared the power with the previously established interests. This process involves much more than just personnel turnover resulting from "death, retirements, or legal restrictions." 19 Significantly, it is replacement within the elite of personnel reflecting the new ideologies of social or economic transformations of the society or the rise of talented individuals from the lower classes. This typification of elite circulation in the United States has been central to the high degree of stability which has characterized the system.

In an attempt to understand the reasons or causes for the change of composition in elite circles within the historical framework of the 
United States, theorists have pointed to the interplay of American democratic institutions with the transformations of the social and economic forces of the nation. ${ }^{20}$ Economic and social forces have undermined the viability of established elites and strengthened the credibility of counter-elite forces, and elections have contributed to the facilitation of entry of these non-elites to ruling positions. But the role of the electorate has been of secondary importance ${ }^{21}$ in this process since the rising power of non-elite groups has directly related to the economic and political technological conditions which determine its success or failure. Thus the electorate is limited in its choice due the high attrition rate of the aspiring non-elites to power positions. Before a counter-elite force presents itself as a viable alternative to the electorate, it has usually modified its stance (as the elite has its position) as to fall within the parameters of elite acceptance.

Within the constructs of a procedural democracy which operates via the political vehicles of elections, rights of political association, and the freedoms of speech and press, elites, are at least nominally held in check as to the extent of their rule. Although in the purist interpretation of elite theory it is stated that elites rule in every society, nevertheless elites rule and behave in a more moderate, if not different manner in "democratic" societies where the dictates of rule are widely acknowledged and accepted. As one theorists notes:

To see elites as the central actors in history is not to see them as unconstrained and operating without limits. Elites are seldom all-powerful and completely autonomous of restrictive social process. Elites are limited in the first place by the policy priorities and political procedures already established in the society, especially where these priorities and procedures are widely accepted. 22 
While any political action undertaken by an elite might be considered possible, it is highly improbably that blatant violations of democratic traditions would occur in an open society claiming democratic techniques of rule.* To perform the functions of rule in the United States otherwise would or could cause immediate breakdown within the elite consensus and jeopardize the stability of the system which has nurtured the continuance of elites. Therefore completely authoritarian measures, and the stifling of social and economic transformations have been avoided by the elites to ensure their own perpetuation and that of the system as well. These constraints on the elite are also evidenced by the procedures of democracy which have facilitated the circulation of elites. The political levers of elections and freedoms of access to press and speech, while not crucial to the emergence of counterelites (which hasten the circulation process), have served as indicators of mass preference and toleration. Elites may bear no recognized accountability to the masses, but in order to survive as an elite ruling group, accountability to the system has been essential.

The history of American elites is not limited to the history of political elites as the political arena is but one stronghold of power in the United States. Elites have operated within other areas as wel1. ${ }^{23}$ With the advent of the industrial revolution, corporate

* For instance, the calling off of elections, the dismissal of Congress, or complete censorship of the press would be flagrant displays of unconstitutionality and therefore intolerable. 
policy has increasingly shaped the direction of the American economy which has had broad implication for governmental policy. In order for the political economy to run smoothly without major breakdowns, the relationship between these two paramount sectors of American society must both be characterized by consensus and stability. The Great Depression of the 1930 's precipitated a breakdown in both the viability and effectiveness of these two elite groups to rule. What emerged from the chaos were the foundations for a positive or welfare state which has produced great changes within the American system without substantially altering or destroying its basic infrastructures. Analyzing these events within the framework of the elitist perspective should provide some novel interpretations in the history of America's recent past. 


\section{ENDNOTES}

p. 29.

${ }^{2}$ Thomas R. Dye and L. Harmon Zeigler, The Irony of Democracy (Belmont, California, 1970), p. 9.

${ }^{3}$ See John Stuart Mill, Representative Government (New York, 1935), p. 203; Carl Becker, Modern Democracy (New Haven, Connecticut, 1941), pp. 26-28; and George Sabine, A History of Political Theory (New York, 1950), pp. 517-541.

4 James Burnham, The Machiavellians (New York, 1943), pp. 236-237.

5 Kenneth Prewitt and Alan Stone, The Ruling Elites (New York, 1973), p. 2.

6avid Truman, "The American System in Crisis," Political Science Quarterly, IXXXIV (1969), p. 489.

${ }^{7}$ Dye and Zeigler, The Irony of Democracy, p. 2.

8 Ibid., p. 323.

${ }^{9}$ See C. Wright Mills, The Power Elite (New York, 1956), pp. 269-278; Dye and Zeigler, The Irony of Democracy, pp. 57-58; and Prewitt and Stone, The Ruling Elites, pp. $31-32$.

${ }^{10}$ Prewitt and Stone, The Ruling Elites, p. 32.

11 James H. Meisel, The Myth of the Ruling Class (Ann Arbor, 1958), pp. $370-371$.

${ }^{12}$ See especially Gabriel Kolko, The Roots of American Foreign Policy, (Eoston, 1969), p. 7 and Prewitt and Stone, The Ruling Elites, p. 136 . p. 84 .

${ }^{13}$ Gabriel Kolko, Wealth and Power in America (New York, 1962),

14 Prewitt and Stone, The Ruling Elites, p. 139.

15 Robert A. Dah1, Who Governs? (New Haven, Connecticut, 1961), pp. 16-18.

16 Prewitt and Stone, The Ruling Elites, p. 145. 
17 Mills, The Power Elite, pp. 225-241.

${ }^{18}$ See Gaetano Mosca, The Ruling Class (New York, 1939, translated and revised by Hannah D. Hahn and Arthur Livingston), p. 460 and Vilfredo Pareto, The Mind and Society (4 vols., New York, 1935, translated by Andrew Bongiorno and Arthur Livingston), IV, paragraphs 2477-2485.

19 Prewitt and Stone, The Ruling Elites, p. 169.

20 Dah1, Who Governs?, pp. 25-60; Mi11s, The Power Elite, pp. 292-297; Prewitt and Stone, The Ruling Elites, pp. 178-182; and Kolko, The Roots of American Foreign Policy, p. 26. 1960),

${ }^{21}$ E. E. Schattschneider, The Semi-Sovereign People (New York, ${ }^{22}$ Prewitt and Stone, The Ruling Elites, p. 233.

${ }^{23}$ See Gerhard Lenski, Power and Privilege (New York, 1966) pp. 5-10; Mills, The Power Elite, pp. 269-297; Floyd Hunter, Top Leadership USA (Chapel HilT, North Carolina, 1959), pp. 160-191; G. Willaim Domhoff, Who Rules America? (Englewood Cliffs, New Jersey, 1967), pp. 10-11; and Suzanne Keller, Beyond the Ruling Class (New York, 1963), pp. 19-21. 


\section{CHAPTER IV}

\section{THE EMERGING COUNTER-E!ITE}

IN THE SOCIAL SCIENCES

During the first hundred years in the history of the United States, lawyers traditionally comprised the ruling elite in the management of government affairs. 1 By the beginning of the twentieth century, this ruling minority, trained in the fields of jurisprudence, no longer held the necessary credentials for administering the fast growing industrial state, because the complicated and "collosal dimensions" of the new societal organization and industrial expansion demanded the expertise of professionals specializing in the study of society. The Progressive movement, based on the ideals of government and societal reform, hastened the recruitment of professionals from the various disciplines of the social sciences, and gave these men a role in the shaping of a new and changing society. ${ }^{2}$ During this period, at the turn of the last century, "the attention of both scientists and reformers was inevitably drawn to the changing character of American society, to the effects of industrialization, immigration, urbanization, corporate concentration and political corruption." 3 In these endeavors, the climate of the Progressive movement joined the talents of the reformers and the social scientists which created a reform movement based on the evidence of social intelligence derived from the data of investigation and research provided by the social scientists. And with the widescale acceptance of the Progressive 
platform, social scientists in growing numbers entered into government service and demonstrated that the "intellect could be politically effective." 4

The trial ground for the role of intellectuals in public service was not Washington, but the state capitals which first offered the example of recruiting experts on a wide scale for government service. Madison, Wisconsin was such a place. During the Progressive period, the much acclaimed "Wisconsin idea" significantly altered the political experience of the state. ${ }^{5}$ The "Wisconsin idea," based on the promotion of the study of law, politics, economics, and history in the university in order to train experts equipped with the necessary skills to manage government affairs, redefined the role of the university to the society. The promoters of the "Wisconsin idea," especially Professors Richard T. Ely, Frederick Jackson Turner and Thomas C. Chamberlain, envisioned the university as a non-partisan entity, serving the people as a whole by offering information, statistics, advice and skill to the political process. Robert Lafollette, during his governorship of Wisconsin in the early 1900's, shared this view of the role of the university. He called upon the university for experts to advise his political machine in the areas of tax reform, railroad control, and direct primary legislation. His sympathy for the "Wisconsin idea" fostered political recruitment from the university of experts proficient in the social sciences, and significantly facilitated the growth of independent services established by experts outside the government to supplement the political mechanism. The Legislative Reference Service, established by Charles McCarthy, a University of Wisconsin graduate student, was this type of 
service organization which sorted out vast amounts of information, and investigated complex problems pertinent to the legislature. By these efforts, Wisconsin demonstrated to the nation the viability of an integrated political arena of experts and politicians. By the time the Progressive platform gained national acceptance under the presidencies of Theodore Roosevelt and Woodrow Wilson, the need for the placement of experts in government was at least publicly acknowledged, if not wholly practiced. 6

The presidencies of both Roosevelt and Wilson "encouraged the belief that ideas had a vital part in government; but at the same time neither was entirely in sympathy with his intellectual contemporaries, and neither enjoyed their full confidence. "7 Roosevelt recruited experts for advice on railroad control, immigration, and meat inspection as well as attracting such intellectuals as Felix Frankfurter, James Garfield, and Gifford Pinchot into government service. ${ }^{8}$ While he mobilized men of talent into the political arena, Roosevelt was also quick to denounce "heterdox" ideas of the intellectuals as in the case of the muckrackers whom he viewed as stirring up "revolutionary ideas." 9 Although many intellectuals and experts won the admiration of Roosevelt, they were neither recruited nor utilized to any great extent in his administration. Woodrow Wilson, himself a political scientist, had little regard for experts. During his presidential campaign of 1912, he stated:

What I fear is a government of experts. God forbid that in a democratic country we should resign the task and give the government over to the experts. What are we for if we are to be scientifically taken care of by a small number of gentlemen who are the only men who understand the job? 10

This reflected the Wilsonian belief that big business, vested interests, 
and experts comprised a solid combine that could only be broken by returning government to the constituency. ${ }^{11}$ However, the experience of his presidency which eventually involved the execution of a wartime foreign policy altered Wilson's perception of the intellectual and the expert. In order to win the war and influence the peace, Wilson needed the aid of the intellectual community. Therefore, during the course of World War I, he recruited academics into government service:

Historians and writers were mobilized for propaganda and experts of all kinds were recruited as advisers. Military Intelligence, Chemical Warfare, the War Industries Board swarmed with academics, and the Washington's Cosmos Club was reported to be "little better than a faculty meeting of all the universities."12

This recruitment underlines the need for expertise on the national level to successfully wage a modern war. The social scientists and experts, mobilized in Washington, effectively performed the tasks inherent in the execution of a war. By the establishment of the War Industries Board, under the chairmanship of Bernard Baruch, the economic mobilization of the country's resources was both quick and efficient with minimal waste of manpower or resources. ${ }^{13}$ With the added wartime responsibilities of the federal government, more extensive sources of information and statistical services were needed for the centralized control of the war effort. The war both magnified the inadequacy of the existing services and supported the development of more accurate services in the compilation and interpretation of raw data. ${ }^{14}$ The work of the psychologists, for example, previously tested in the areas of human behavior such as sensation, reaction, learning, memory, and attention was utilized by the military during the war especially in the 
organization of a program of controlled testing of the troops, and in the formulation of the Alpha and Beta controls in intelligence testing. ${ }^{15}$ The Wilson administration also recognized that success at the Peace Conference would require expert knowledge in the fields of geography, economics, ethnology, history, international law, and strategy since these fields would comprise the primary focus of the peace talks. Late in 1917, Colonel House began recruiting experts in these fields from the universities. From this recruitment, he formed a group known as "the Inquiry" 16 which operated independently of the regular diplomatic channels of the State Department, since the department staff lacked the necessary personnel. The staff of "the Inquiry", which included some 150 experts, accompanied Wilson to Paris where it played a significant role in the negotiations. These illustrations point out the widespread integration of academics and intellectuals in the wartime federal bureaucracy, but the association between the experts and the old guard politicians ended as the nation retreated into isolation at the war's end. ${ }^{17}$

From the initial years of the twentieth century through the close of World War I, the utilization of experts and intellectuals by the government altered constantly between limited recruitment and dismissal. The experiences of the social scientists and experts in the government during this period, however limited, did provide the stimulus for the necessary advancements required by the disciplines before the application of these fields of social intelligence would be a viable instrument of governmental policy. Although the political experience underlined the shortcomings of the professions to cope with the dilemmas of modern society, the retreat from political life in the Twenties gave the 
intellectuals the time to advance the methodology of their various professions.

The mood of the Twenties in the academic community involved in social science research was optimistic:

Sociologists of the period, full of the elan of their new subject, exuitant over the apparent defeat of religious obscurantism, were as optimistic as the businessman and the historian, though for different reasons. Their New Era lay in the future rather than the present; its motivating force was not technology alone, but the guiding social intelligence. 18

Because of the advances made in the social sciences in the previous two decades, these professions abandoned the "sentiment, impressionism, and introspection" that had dominated to a large degree their research and sought to derive and establish new methods for the quantification and interpretation of information which they increasingly felt would act as a "guide for practical statesmanship." As one student of the Twenties explained, social scientists were confident that they, as a new elite, would be able to lead mankind "out of the fog of dissolving tradition and toward the end of controversy and the reign of universal efficiency." 19

The Twenties precipitated the rise of new institutes devoted to social science research that were privately supported and independent of the government but which were available to the government for consultation and advice on policy matters. ${ }^{20}$ Realistically, they owed their beginnings to the government's demand for this type of knowledge and information during World War I and to the availability of funds from the private sector, namely from foundations such as the Carnegie Corporation and the Rockefeller Foundation. During this period, "research. . .was 
established as a legitimate government function and, within limits was sustained and supported, especially by Hoover, who was a dominant figure in government in that decade." 21 Having a deep respect for the gathering of information by specialists and experts, Herbert Hoover, in his role as Secretary of Commerce, and later as President, sought to coordinate scientific and social science research with philanthropic support in the private sector in order:

to develop broad channels for cooperative action among influential segments of the society, to support these efforts with scientific and economic advice, and, in the process, to avoid the necessity for action by the central government. 22

His efforts proved emminently successfur. Privately-funded institutes reached new levels of sophistication in information gathering, and explored widely in the fields of public administration, government policy formulation, and economic research. Ironically, Hoover, as President, would resist much of the advice social scientists offered as remedies for the socio-economic chaos created by the world-wide depression which began in 1929. Nevertheless, with the encouragement of men like Hoover, and with the establishment of the institutes of research, the potential of social science as an instrument of government policy came close to realization by the end of the decade.

The National Bureau of Economic Research was in its conceptual and tentative planning stages before the outbreak of World War I in 1917.23 Malcolm C. Rorty of American Telephone and Telegraph Company, and N. I. Stone, a former statistician, became acquainted in conjunction with unemployment and legislative alternatives in New York. After several disputes over economic policy, they decided jointly to set up an organization 
devoted to research on controversial economic subjects of national interest. Rorty and Stone contacted three major economists with different view points: Wesley Mitchell of Columbia; Edwin F. Gay of the Harvard Business School; and John R. Commons of the University of Wisconsin, and formerly of the LaFollette's brain trust. With their enthusiastic support, Rorty and Stone started preliminary planning and began seeking financial backing. The outbreak of the war delayed further planning, but as soon as the war ended, Rorty secured the necessary financial support, and by 1920 the National Bureau of Economic Research was launched with Mitchell as Director of Research. 24

Under the auspicies of Mitche11, long-term research, based on national income and its distribution, and business cycles, occupied the attention of the Bureau. ${ }^{25}$ During the course of the Twenties, experts such as Simon Kuznets developed theories of a complex nature involving national income estimates. While such preoccupations commanded most of its attention in its first decade of operation, the Bureau undertook short-term analyses and projects as wel1. At the government's request, studies were conducted on unemployment in conjunction with the Conference on Unemployment in 1921. In response to Hoover's interest on the effects of unemployment on economic change, the Bureau did several reports for the federal government. Such short-term analyses, however, were considered by researchers such as Mitchell as having little significance in the creation of fundamental knowledge, since changing conditions more often than not refuted research findings and invalidated their conclusions. of this experience, he notes: 
Our experience with ad hoc investigations confirms the opinion that they contribute less in the long run to the knowledge men need, and less to the practical treatment of social ills, than systematic studies of broader and more fundamental character, 26

Despite the obvious shortcomings of the short-term assignment type of research undertaken at times by the Bureau, the expertise gained in fundamental and long-term research provided invaluable experience for the economists involved.

The Institute for Government Research was established along many of the same lines as the National Bureau of Economic Research, and for similar purposes. 27 Derived from the notion that "there should be a non-partisan, independent institution to consider the problems of public administration, and particularly those of the National Government," 28 the Institute received its original conceptualization for organization from the Comission on Economy and Efficiency appointed by President Taft in 1910. The Commission's emphasis was on the managerial role of the President, and the use of the budget as a lever in executive management. The Institute, an outgrowth of this Commission, was created by the principal staffers* of the Commission and received financial backing from the Rockefeller Foundation. Frank J. Goodnow, the President of John Hopkins University, chaired the board of the Institute's Directors and William F. Willoughby, a leader in the field of budgetary reform, directed the staff. Adhering to Goodnow's contention that policy and administration must be separate, the Institute defined its function as study and research

* Members of the staff of the Commission on Economy and Efficiency later associated with the Institute for Government Research included: W. F. Willoughby, Frank J. Goodnow, Henry S. Chase, and Merritt 0 . Chance. Rexford Tugwel1, The Enlargement of the Presidency (New York, 1960) p. 398. 
upon which reforms, at the instigation of the President or Congress, would be based. Besides working on budgetary reform, the Institute, during the Twenties, concentrated on analyzing, office by office, the Executive Branch of the federal government. A series of monographs, summarizing the study's findings, provided a basis for later reforms. ${ }^{29}$ Constantly running into financial difficulties, the Institute frequently relied on the fund-raising of Robert S. Brookings, a financier from St. Louis, and in 1928 the Institute for Government Research was incorporated into the newly established Brookings Institution.

Robert S. Brookings laid the early foundations for the Brookings Institution while organizing the Institute for Economics with funds from the Carnegie Corporation. ${ }^{30}$ Unlike the National Bureau of Economic Research whose primary focus was on economic methodology, the Institute for Economics dedicated itself to analysis and problem-solving. Under the guidance of its director, Harould Moulton, the Institute addressed itself to the "questions of international economic reconstruction and the effects of international policies on commerce, agriculture, industry, and labor." 31 In 1924, Robert Brookings also acquired funding for the Graduate School of Economics and Government in Washington, D. C. which was loosely associated with both the Institute of Economics and the Institute for Government Research. By 1928, funding for the three distinct organizations became impossible, so they merged into what became known as the Brookings Institution. Several changes followed: the Graduate School was abolished and replaced by a training division, while the two Institutes retained their separate identities as distinct divisions of the larger enterprise. The Brookins Institution, 
based in Washington, D. C., continued to operate for the development of the social sciences with particular emphasis on their application to the national government.

The National Bureau of Economic Research as well as the Brookings Institution underlined the trend toward specialization and isolation among the various disciplines of the social sciences in their post-war development. This trend led to the founding of the Social Science Research Council (SSRC) whose purpose was to instigate interaction among the various disciplines of the social sciences. ${ }^{32}$ The focus of the SSRC was not research but rather on the methods of improving research conditions in the universities, and on strengthening the general understanding of the nature and structure of the social sciences. As political scientist Gene Lyons explains:

Because it was a council of all the social sciences, its intellectual base was broader than that of either the Bureau or Brookings. . . Less exclusively concerned with economic analysis than the National Bureau, the SSRC was more inclined to view economic problems in terms of a socio-economic mix; and, in the study of government, it was less wedded to the goals of efficiency and economy than the Institute for Government Research, and more disposed to examine the social and psychological determinants of politics and administration. ${ }^{33}$ Charles E. Merriam, ${ }^{34}$ a professor of political science at the University of Chicago, was the driving force in making the SSRC a reality. Merriam went beyond the historical, legalistic approach of his discipline that had preoccupied the professionals of political science to a study of "systematic politics." This involvement with the relationship of scientific knowledge to political power consumed most of Merriam's productive academic life and convinced him of the need for interdisciplinary scholarship. Throughout his career, Merriam 
intermittently served in the tangible world of politics and government, chairing such groups as the City Council of Chicago, President Hoover's Research Committee on Recent Social Trends, and eventually Franklin Roosevelt's National Planning Board. In the early Twenties, however, Merriam's chief concern was the SSRC, its acceptance among the various social science associations, and its financial support. Having received enthusiastic academic support, Merriam secured financial backing from the Laura Spelman Rockefeller Memorial.* In December of 1923, Merriam formally incorporated the SSRC as a cross-disciplinary research institute of all social sciences.

From the start, the staffers of the SSRC, under Merriam's direction, attempted to work out the details involved in the SSRC's two main objectives: the promotion of the development of social science as a whole and the improvement of the training of social scientists. To facilitate the latter objective, a program of fellowships and research grants was established to "increase the number of social scientists, to improve their preparation, and to support their investigations through financial assistance for travel, facilities, and equipment." 35 The implementation of the overall promotion of social science proved much more difficult. The field was divided into many varied disciplines, all at different stages of development, and with their own traditional and methodological backgrounds. The SSRC proceeded slowly to attack

*From 1922 to 1929, Beardsley Ruml, a colleague of Merriam's from Chicago, served as the director of the Laura Spelman Rockefeller Fund, and as a result more than $\$ 40$ million was distributed to the SSRC, the National Bureau of Economic Research and the Brookings Institution during this period. Gene M. Lyons, The Uneasy Partnership (New York, 1969), p. 44 . 
the problem and within three years produced a methodological study based on a "case book" approach which described the methods available to the various disciplines but which issued no judgmental opinions. ${ }^{36}$ This cautious but sensible policy averted intense hostilities that might otherwise have developed. In the long run, too, the assessments published by the SSRC on the methodologies of the social sciences served as guideposts for universities at large.

The SSRC also "lobbied" for the publication of social data collected by the Census Bureau and other government offices handling statistical studies. This material was usually not available to social scientists and prevented them from assessing evidence with such a wide sample as that accumulated by the federal government. Their efforts proved successful, and with the availability of wide-sample statistics, the SSRC, with its cross-disciplinary staff of experts, made great strides toward the assesment of social problems. Merriam took a strong stance on the involvement of social scientists in the analysis of governmental concerns which, he felt, would eventually include social scientists in the decision-making process. One scholar notes:

It was obvious that social decisions and actions would be taken with or without the application of knowledge. In the absence of involvement by social scientists, the direction of social change would be left to "the fanatic, radical, or reactionary whose pattern fits him for propaganda rather than science. "17

To prevent "the absence of involvement by social scientists" in the formulation of nation policy, the SSRC, under the direction of Merriam, functioned as a close observor of national policy.

It was not long, however, before Merriam received an even greater opportunity for social science to work in a closer relationship with the 
national government. In 1929, President Hoover requested a study of the recent social trends of the country and established the Research Committee on Social Trends. ${ }^{38}$ Utilizing the key social thinkers from the various social science institutes, Hoover named Mitchell as Chairman, Merriam as Vice-Chairman, and William Ogburn, a prominent sociologist on the staff of the SSRC, as Director of Research. Consistent with his policy of government "economy and efficiency", the President obtained funding for the project from the Rockefeller Foundation and delegated the bookkeeping duties to the SSRC administrative body. For the first time, a comprehensive analys is encompassing the entire range of social science was initiated by the request of the Chief Executive of the federal government.

Ironically the years from 1929 until late in 1932, when the major report of the Committee was published in Recent Social Trends in the United States, proved disastrous for the nation's economy. "Hoover had never lacked for information about the economy and about the factors of change and possible dislocation." 39 Although it could be argued that the information made available to Hoover was incomplete, he had, during the course of his long tenure in the federal government, accomplished much success in improving the methods of economic forcasting. He had launched academic studies, updated the statistical services, established committees and conferences, and utilized experts and advisors. Indeed, as early as 1928, Hoover convened the Committee on Recent Economic Changes to survey and analyze the nation's economy. The report of the Committee, 40 issued in early 1929, warned the government of the possible danger of the interdependent nature of the nation's economy regarding the imbalance of 
the different economic sectors on the overall economy. The report underlined the necessity for equilibrium: "that through ignorance of economic principles or through selfish greed, or inadequate leadership, the steady balance will be disturbed to our economic detriment." 41 Given this expert opinion, Hoover left it for the private sector to digest and take the necessary precautions, since he saw the role and function of the federal government in a non-interventionist light. One student of the Hoover era illustrates the manner in which Hoover utilized the intellectuals and experts:

The experts would gather, sift, and weigh the facts. But the findings of these voluntary groups were not to be used as a springboard for executive action. To use them for this purpose, the President said, was "anathema." Instead, the information was to be given to the people. When possessing the facts, the people would judge. 42

When the Great Depression finally crippled the nation's economy in a seemingly irreversible fashion, Hoover attributed the major causes to Europe's economic mismanagement and to speculations in the securities market at home. ${ }^{43}$ Since it was caused, in his estimation, by the "selfish greed of a few" in the private sector, he felt that it was up to the business community to reform and fortify itself without reliance on federal intervention, but rather through cooperation promoted and guided by federal leadership. 44 Inaction did certainly not typify the administration of Herbert Hoover, but the executive actions taken did little to reverse the economic chaos. Philosophically bound to the credo of American individualism and voluntarism of the private sector, he never carried his executive program to the point of government intervention which he felt would have jeopardized the American system as he envisioned it. In the final months of his administration, Hoover did expand the 
government's role in attempting to curb economic displacement by sending "a series of legislative proposals to Congress to avert complete collapse of the nation's economy; he asked for a cutback in government expenditures, a sales tax, legislation to avert banking closures and bankruptcy, and authority to ease pressures on mortgage payments. "45 But by then it was too late. His administration was drawing to a close, and the economic outlook of the nation had never looked so bleak with no significant relief realized or realistically anticipated.

These practices of Hoover present a paradoxical problem. Throughout the Twenties, Hoover was one of the leading advocates of the integration of social science into the governmental decision-making process, yet during the depression he failed to utilize the advice of the social scientists to reverse the disastrous economic trends of the nation through government intervention. ${ }^{46}$ Hoover repeatedly demonstrated his respect for the methods and advances made by the social sciences in the upgrading of the political process in their work of introducing the means to formulate social and economic policy in an accurate and intelligent fashion. Yet his adherence to the outdated political credo of individualism and voluntarism, coupled with his beliefs of governmental non-intervention, prevented Hoover from performing the necessary tasks required to bring the nation out of the depression, and, more importantly, into the modern era.

During the initial years of the depression, the Research Committee on Social Trends undertook not only an exhaustive investigation of the social components of American life over the previous two decades, but also addressed themselves to the task of making recommendations they 
deemed necessary for adoption by the federal government. ${ }^{47}$ In their findings, which encompassed a wide breadth of American social and economic life, the social scientists stressed that the problems of the social order stemmed from the fact that interrelated changes occuring in society among its various components were "going forward in such bewildering variety at various speeds" that a grave imbalance had displaced the social equilibrium. ${ }^{48}$ To even out the imbalances in the social structure called for a conscious and concerted effort upon the part of government as "the objective of any conscious control over the process is to secure a better adjustment between inherited nature and culture." The report of the Committee further stated that the "means of social control is social discovery and the wider adoption of new knowledge." 49

In its suggestions and recommendations, the Committee proposed the creation of a "National Advisory Council" which would include in its membership" scientific, educational, governmental, and economic points of contact. . .able to contribute to the consideration of the basic social problems of the nation." 50 Such a council would go beyond the "purely economic planning" and the "purely governmental planning" considerations, and provide a new synthesis for policy-making:

The new synthesis must include the scientific, the educational, as well as the economic (including here the industrial, and the agricultural) and aiso the governmental. All these factors are inextricably intertwined in modern life, and it is impossible to make rapid progress under present conditions without drawing them all together. 51

The Committee also proposed the reorganization of the executive branch of the federal government as its existing structure prevented efficient administration which was vital to meet and control the challenges of 
modern society. In light of the failures of the federal government to administer to the highly modernized American society, the Committee looked for the advent of new types of government organization according to the constitutionally defined branches of government, but also in adherence to the demands of modern society. Such governmental structures might include: "the quasi-governmental corporation, the government-owned corporation, the mixed corporation, and the semi- and demi-autonomous groupings in varying relations to the state. ${ }^{152}$ Such new advances by the government into the private sector posed no threat for these students of society as the movements would only be in keeping with the changes already having taken place in society, and would enable the government positively to enter into the modern era.

Not tied to the Hoover administration, which had not taken their advice of the need for more effective government intervention and regulation of the economy, the Conmittee on Recent Social Trends looked to the new administration of Franklin Roosevelt for the instigation of the reform and direction the Committee members deemed necessary to lead the nation out of the depression and into the modern era. Though their proposals were often vague and non-specific, the Committee advocated:

nothing less than the fullest application of knowledge and intelligence to the whole decision-making process in society. It proposed to apply the very methods that social scientists had employed in writing Recent Social Trends to the formulation of public policy: combining qualitative intrepretation of trends with quantitative statistical measurements and putting them to work in making major political decisions. 53

The mood of the social science community at the coming of the new administration was like that of the nation at large--expectant 
with the fierce hope that something would be done to rectify the national economic failures.

The advances made by social sicence in research and methodology during the Twenties as well as the role social scientists played in their advisory capacities to government officials via the institutes underlines a broader conception of the role of the social science community to the political structure, During this period, whether it was a conscious effort or not, the social science community comprised the beginnings of an effective counter-elite. According to elitist thought, a counter-elite is the prototype of a new sort of personnel reflecting ideas which are in conflict with the major assumptions or methods employed by the ruling class, in this case businessmen and their allies. By the close of the decade, the main contentions of the social science research groups throughout the country held that the existing practices of executive authority were no longer effectively governing the nation and called for the implementation of the new synthesis of thought to reconstruct the chaotic climate of the nation's social fabric. As yet, social scientists were not given the opportunity to chair the staffs of the political advisory committees which mold the thought of the political leaders, but, during their interim out of government in the Twenties, they fully prepared themselves for such roles in the future. They waited, anticipating the opportunity to carve out a new alternative to the "savage dependence upon catastrophies for progress. "54 And consistent to elite theory in the United States, the integration of the social scientists into positions of political power was gradual 
and non-violent. They found their opportunity to share rule and effect change during the presidency of Franklin D. Roosevelt. 


\section{ENDNOTES}

${ }^{1}$ Kenneth Prewitt and Alan Stone, The Ruling Elites (New York, 1973), pp. 32-35. See also Walter Lippmann, Public Comment (New York, $1965)$, pp. 233-235.

${ }^{2}$ Gene M. Lyons, The Uneasy Partnership (New York, 1969), pp. 23-25 and Richard Hofstadter, Anti-Intellectualism in American L ife (New York, 1963), pp. 197-214.

3yons, The Uneasy Partnership, pp. 24-25.

${ }^{4}$ Hofstadter, Anti-Intellectual ism in American Life, p. 199.

${ }^{5}$ For a discussion of the "Wisconsin idea" and its incorporation in the politics of Wisconsin see: Charles McCarthy, The Wisconsin Idea (New York, 1912), pp. 1-19; 88-273 and Frederick Jackson Turner, "Pioneer Ideals and the State University," The Frontier in American History (New York, 1920), pp. 285-289.

${ }^{6}$ B. P., "College Professors and the Public," Atlantic Monthly, IXXIX (February, 1902), pp. 284-286 and "Literary Men and Public Affairs," North American Review, CLXXXIX (1909), pp. 53-56.

7 Hofstadter, Anti-Intellectual ism in American Life, p. 207.

${ }^{8}$ George Mowry, The Era of Theodore Roosevelt (New York, 1958), pp. 250-253, 172-175.

${ }^{9}$ Richard Hofstadter, "Theodore Roosevelt: The Conservative as Progressive," The American Political Tradition (New York, 1948), pp. 223224 and Mowry, The Era of Theodore Roosevelt, pp. 206-]09.

10 John Wells Davidson, ed., A Cross Roads of Freedom: The 1912 Campaign Speeches of Woodrow Wilson (New Haven, T956), p. 83.

11 Arthur Link, Wilson: The New Freedom (Princeton, 1956), pp. 62-65, 242-243.

${ }^{12}$ Hofstadter, Anti-Intellectualism in American Life, p. 211.

13 Bernard M. Baruch, American Industries in the War (Washington, D.C., 1921), especially pp. 5-15.

14 Iyons, The Uneasy Partnership, pp. 26-27. 


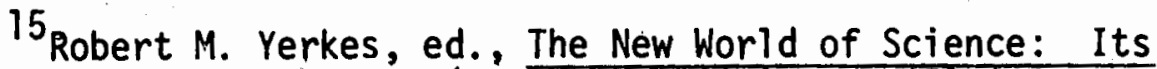
Development During the Har (New York, 1920), pp. $351-380$.

${ }^{16}$ Sidney Edward Mezes, "Preparations for Peace" in Edward Mandell House and Charles Seymour, eds.; What Really Happened at Paris (New York, 1921), pp. 1-8.

17 Lyons, The Uneasy Partnership, p. 31 and Hoftstadter, AntiIntel lectual ism in American Life, p. 213.

${ }^{18}$ Henry F. May, "Shifting Perspectives on the 20 's," Mississippi Valley Historical Review, XIIII (1956), p. 407.

19 Ibid., p. 407. See also John Candler, "The Social Sciences," American Journal of Sociology, (Chicago) XXXI (1926), pp. 721-732 for another strong statement concerning the positive prospects of the social sciences. Loren Baritz, The Servants of Power (Middletown, Connecticut, 1960), pp. 3-96 is a survey of the work accompl ished by social scientists in industry during the Twenties.

20 An exception to the institutes of the private sector was The Bureau of Agricultural Economics formed during the farm prices panic of 1920-21 from centralizing smaller research units in The Department of Agriculture. Its main emphasis was investigating the question of effective production control. Lyons, The Uneasy Partnership, p. 33 notes: "The experience of The Bureau of Agricultural Economics demonstrated the growing importance of social science research as a continuous and integrated activity in government. If there were limits to the role of research in agriculture policy, this was a reflection of the limited role of government itself in the economy." See also Richard S. Kirkendall, Social Scientists and Farm Politics in the Age of Roosevelt (Columbia, Missouri, 1966), pp. 11-30 for a discussion of the early foundations and work of the Bureau during the Twenties.

$$
\begin{aligned}
& 21 \text { Lyons, The Uneasy Partnership. pp. 33-34. } \\
& 22 \text { Ibid., pp. 34-35. } \\
& 23 \text { See N. I. Stone, "The Beginnings of the National Bureau of }
\end{aligned}
$$
Economic Research," Twenty-Fifth Annual Report, National Bureau of Economic Research (New York, 1945), pp. 5-10 for a history of the founding of the Bureau.

${ }^{24}$ Ibid., p. 9.

${ }^{25}$ The work of the Bureau during the Twenties is discussed in Wesley C. Mitchell, "The National Bureau's First Quarter Century," Twenty-Fifth Annual Report, Nationl Bureau of Economic Research (New York,

${ }^{26}$ Ibid., p. 15. 
${ }^{27}$ See Charles B. Saunders, Jr., The Brookings Institution: A Fifty Year History (Washington, D. C., 1966), pp. 12-27 for the historical foundations of The Institute for Government Research.

28 quoted in Lyons, The Uneasy Partnership, p. 38.

${ }^{29}$ An example of the monographs published by the Institute is

Lewis M. Meriam, The Problem of Indian Administration (Baltimore, 1928). It served as the basis for the later reorganization of The Bureau of Indian Affairs (BIA).

${ }^{30}$ Charles B. Saunders, The Brookings Institution: A Fifty Year History, pp. 27-40.

31 Lyons, The Uneasy Partnership, p. 41

${ }^{32}$ See "History and Purposes of the Social Science Research Council," Appendix A, Fifth Annual Report, The Social Science Research Council (New York, 1929), pp. 39-48 for the history and work of the SSRC.

33 Lyons, The Uneasy Partnership, p. 43.

${ }^{34} \mathrm{~A}$ complete sketch of Charles Merriam's professional life can be found in Barry Dean Karl, Executive Reorganization and Reform in the New Deal (Cambridge, 1963), pp. 37-81.

35 Lyons, The Uneasy Partnership, p. 45.

${ }^{36}$ Stuart A. Rice, ed., Methods in Social Science: A Case Book (Chicago, 1931), pp. v-vii.

37, Lyons, The Uneasy Partnership, p. 46.

${ }^{38}$ Recent Social Trends in the United States (2 vols., New York, 1933), I, P. V.

39-yons, The Uneasy Partnership, p. 50.

40 "Recent Economic Changes in the United States," Report on the Committee on Recent Economic Changes of the President's Conference on Unemployment (New York, 1929), pp. 1-20.

${ }^{41}$ Ibid., p. xx.

42 Albert U. Romasco, The Poverty of Abundance (New York, 1965), p. 17.

43 Ibid. pp. 182-186; Hofstadter, "Herbert Hoover and the Crisis of American Individual ism," The American Political Tradition, pp. 299-302. 
${ }^{44}$ Romasco, The Poverty of Abundance, pp. 24-65; Arthur Schiesinger, Jr., The Crisis of the 0ld Order (Boston, 1957), pp. 230-235; 474-477.

45, yons, The Uneasy Partnership, p. 50.

${ }^{46}$ Ibid., pp. 50-51 and Romasco, The Poverty of Abundance, pp. 17-20.

47 Recent Social Trends in the United States, I, pp. vii-ix.

${ }^{48}$ Ibid., I, p. xx.

${ }^{49}$ Ibid., I, P. $x x$.

${ }^{50}$ Ibid., I, p. xxiji.

51 Ibid., I, pp. xxiij-xxiv.

52 Ibid., I, p. xii.

53. yons, The Uneasy Partnership, P. 49.

54 Wesley Mitchel1, quoted in Lyons, The Uneasy Partnership, p. 49. 
CHAPTER $V$

THE NEW DEAL AND THE NEW ELITE

The inauguration of Franklin D. Roosevelt as President of the United States in the spring of 1933 was a solemn occasion. The mood of the nation was a combination of desperation and insecurity nurtured by the depression which, during its three year course, had adversely affected the American people, turning the prosperity of the New Era into a nightmare of unemployment, financial ruin, and despair. ${ }^{1}$ Americans viewed Roosevelt's ascendency to the presidency with both expectancy and hope. Keenty aware of the solemnity and the uncertainty which characterized the nation on the day of his inauguration, Roosevelt addressed the people of the United States in a serious and sober manner. His address, more symbolic than substantive, set the tone for his coming administration where, he promised, hope and recovery would replace fear and retreat by means of a strong and positive course of action. ${ }^{2}$ In this manner, Roosevelt launched the New Deal.

The election of Roosevelt to the presidency in 1932 marked the culmination of a political career which had begun years earlier. ${ }^{3}$ Schooled in the political atmosphere of Progressivism at the turn of the century, Roosevelt expressed and fulfilled his Progressive orientation in political service. He served as a state senator in the legislature of New York, as assistant Secretary of the Navy in the Wilson administration, as the unsuccessful Vice-Presidential running mate of James Cox in the election 
of 1920, and as Governor of New York during the four years preceeding his bid for the presidency. This road, from the privileged confines of Hyde Park to the White House, prepared Roosevelt for the difficult task of reversing the direction of the deflated economy. More than any of the political arts that he had so skillfully assimilated and adopted on the way to the presidency, Roosevelt's ability to utilize the talents of specialists and academic professionals provided the key to his understanding of the dilemmas of the nation's economy when he assumed its leadership.

During his governorship, Roosevelt consulted frequently with college professors, social scientists as well as public and private administrators for guidance in the formulation of policy and legislative programs. 4 Roosevelt's achievements as governor in the areas of penal reform, farm relief, banking regulation, state aid for the relief of the unemployed, labor relations, unemployment compensation, and public utilities were facilitated by the work of the many commissions staffed by professionals whom he had recruited for the purposes of investigation and analysis. 5 His ability to recruit and utilize experts within the political framework testified to both his political acumen and his administrative ability.

The affairs of the nation, however, were much more complex and demanded the expertise of those able to deal, not only with the technical aspects of implementing policy, but also with the formulation of policy broad enough to cover the economic exigencies of the entire nation as well as the implications of foreign affairs. Therefore, to assist him in his quest for the presidency, Roosevelt established a "privy council" of policy advisors under the direction of Samuel Roseman, his chief 
counsel in Albany. ${ }^{6}$ Roseman first contacted Raymond Moley, a professor of Government at Barnard and Columbia Universities, and Basil $0^{\circ}$ Conner, Roosevelt's former law partner. Moley quickly established himself as coordinator of the group and recruited two of his colleagues from Columbia: Rexford Tugwell, an expert on agricultural economics, and Adolf Berle, Jr., whose comprehensive analysis, The Modern Corporation and Private Property, was published and highly acclaimed that summer.

This "privy council," later coined "brain trust" by James Kiernan of the New York Times, conferred weekly with Roosevelt in Albany, arguing economic theory, drafting memoranda, and composing campaign speeches. Although these five comprised the nucleus of the brain trust, others were consluted and often sent their ideas and plans via memoranda to the group for discussion even if not attending themselves. ${ }^{7}$ From Roosevelt's point of view, these meetings served several purposes:

In the first place, they enabled Roosevelt to clarify his own thinking on the major economic problems, tendencies, and forces of the time. Secondly, they brought him up-to-date on most viewpoints and proposed solutions for the problems; there were few proposals that the brain trust discussions seem to have missed. In the third place, they opened ug new avenues of policy that had not been considered previously.

These conferences were equally valuable for the members of the brain trust. As a forum for the expression of the economic theories and methods which had developed and expanded during the Twenties, the meetings with Roosevelt provided the brain trust a political framework within which their ideas could be analyzed and developed. These men, schooled in the philosophy of John Dewey and Herbert Croly which stressed "that organized social intelligence could shape society, ${ }^{9}$ found in Roosevelt, initially in the Albany meetings, a politician willing to weigh the soundness of 
their counsel. From the beginning, the need and reliance was evenly balanced between Roosevelt and his staff of intellectuals. As "social engineers, 10 the members of the brain trust possessed the knowledge to formulate new policies and programs; and Roosevelt, as "master politician," possessed the skill and the opportunity to translate that theory into a political reality. This relationship, successfully conceived in Albany on the eve of Roosevelt's nomination for the presidency, forshadowed the academic and professional mobilization in Washington, D. C. which continued throughout the entire course of the New Dear.

Roosevelt won the Democratic Party nomination in Chicago and launched a spirited campaign. 11 He traversed the nation exposing a "fresh personality, fresh ideas, and fresh hope." 12 A1though Roosevelt had yet to clearly formulate cohesive administrative policies, he neverthe less articulated a cautious new direction for the federal government throughout all of his major addresses:

At Columbus, Ohio,. . . : reciprocal trade agreements and reduced tariffs, supervision of sales of securities, security exchanges and bank deposits, separation of investment banking from commercial banking.

At Sea Girt, New Jersey. . . : repeal of prohibition amendment.

At Topeka, Kansas. . . a program of agricultural relief, planned land use, refinancing of farm mortgages.

At Salt Lake City. . . : a program for relief of the railroads.

At Portland, Oregon. . . : public development of water power and supervision of public utilities; control of public utilities holding companies.

At Detroit, Michigan. . .: social justice through social action.

At Albany. . . government responsibility for relief and unemployment distress, public works to lessen unemployment, 
unemployment insurance, better housing, health as a concern of the federal government.

At Pittsburg. . . : balancing the budget.

At Springfield. . . : relief for agriculture by raising farm prices, reducing its taxes, and lightening its burden of farm mortgages.

At St. Louis, Missouri. . . : plans for helping the eight great credit groups of the nation.

At Boston. . . : comprehensive program for unemployment, emergency relief, temporary public works, employment exchanges, 13 reduction of work day and of work week, unemployment insurance.

Throughout Rooseveit's entire campaign, the brain trust drafted his speeches, and continued to voice and exhaust opinions on policy formation. ${ }^{14}$ If the campaign schooled Roosevelt in the intellectual consideration necessitated by his candicacy to the presidency during distressing times, it also educated the brain trust in the political realities of the early Thirties. During this period preceding the election, the working relationship between Roosevelt and his brain trust strengthened, and, in the following few months, a new chapter in the political history of the United States began.

Roosevelt won an overwhelming victory in the presidential election of 1932, claiming an edge in popular votes of over seven milition and carrying forty-two states. During the interregnum, Roosevelt relied on the brain trust to interview specialists and prepare drafts for the initial legisiation of the "Hundred Days." 15 As the heir-apparent of the vast political machinery of the federal government, Roosevelt had many political considerations as well as policy directives to coordinate. The presence of Roosevelt's brain trust during his campaign had sparked widespread objections among the media and the political centers of the 
Democratic Party who feared both a government in the hands of intellectuals and a breakdown in the system of party patronage. ${ }^{16}$ Roosevelt, drawing on his vast political experience, recognized the need to incorporate intellectuals and social engineers into the system as well as the political practicalities of awarding prominent loyal party supporters with the fruits of his victory. To have done otherwise would have been political suicide. Therefore, during the interregnum, Roosevelt selected his appointees carefully, and established a delicate balance of traditionalism and liberalism among his chief lieutenants.

The selection of a cabinet provided a key opportunity for Roosevelt to gather and sustain political support for his oncoming administration. What was noteworthy in naming the cabinet was Roosevelt's genius for "giving something to everybody." He divided these presitigious appointments among men of seniority in the Democratic Party, geographical representatives, and spokesmen of the new groups of social action. ${ }^{17}$ of the ten member cabinet, seven positions were filled with conservative old-line Democrats; and the remaining three were staffed with liberals symbolizing the new prototype of personnel in the federal government. Cordell Hull, Claude Swanson, and Daniel Roper appointed to the Departments of State, Navy, and Commerce respectively, completed the southern contingent in the cabinet. Save for Cordell Hull, who had demonstrated his skilled talents of negotiation throughout his congressional career, the importance of this contingent was more in its prestige among Southerners than in the capabilities of its membership. To direct the Departments of Treasury and Justice, Roosevelt turned to William Woodin, industrialist, and Homer S. Cummings, senior lawyer. Both of conservative persuasion, but 
nevertheless ardent Roosevelt supporters, they were selected as representatives of the northeast quadrant. To satisfy the patronage demands of the Democratic Party, Roosevelt named James A. Farley, Democratic National Party Chaiman, and Gov. George H. Dean of Utah, longtime advocate of the spoils system, to the top posts in the Departments of Post Office and War. This traditional approach of selection for the majority of the cabinet consolidated and strengthened Roosevelt's position among his party. Tugwel1, a Roosevelt advisor during this period, comments on Roosevelt's initial appointments:

His first selections were obviously intended to consolidate his coalition and to make it likely that even the most reluctant members would accept his directions. It was weighted heavily with southerners whose support he had to have--southerners would chair all congressional committees-and who would be the most reluctant to swallow the medicine he expected to prescribe. 18

Roosevelt turned to the faction representing the new prototype of politicians--the aspiring liberal activists, for the remainder of his cabinet appointees. To fill the head positions in Agriculture, Interior, and Labor, he selected Henry A. Wallace, "a symbol of reform in the agricultural picture," Harold Ickes, a leading Midwestern political reformer, and Frances Perkins, a labor authority in the state cabinet of New York. On the whole, Roosevelt's Cabinet did not reflect any but political interests. His scheme to consolidate support and fortify his own position through the symbolic appointments to the cabinet served him well during the early years of his administration.

Roosevelt deployed the none too popular or politically expedient business leadership to posts abroad. ${ }^{19}$ Prominent businessmen of the Democratic Party had generously supported Roosevelt's bid for the 
presidency, and such support was traditionally repaid with a cabinet or high ranking position in government. To ward off possible conflicts or administrative difficulties with a representative of business among his chief lieutenants, Roosevelt defied tradition and offered less sensitive positions instead. Because of this policy, Jesse Straus, who awaited his appoirtment to the Department of Commerce, went instead to head the embassy in Paris. Such was also the case for David H. Morris who went to Belgium, and Barry Bingham who headed the delegation in London.

Behind the symbolic appointments of the interregnum were, more significantly, the appointments of officials who would chart the course of Roosevelt's initial recovery program. As the chief executive was not allowed, by law, in 1933 to employ administrative assistants, Roosevelt appointed Moley to Assistant Secretary of State and Tugwe11 to Assistant Secretary of Agriculture in order to keep the nucleus of his brain trust centered in Washington. Similarly, Adolf Berle, Jr., served as a special advisor to the Reconstruction Finance Corporation (RFC).

The chief concern, in the days surrounding the inauguration, was the formulation of policy to meet and reverse the economic crisis. As political scientist Charles E. Jacobs notes:

It was a situation that called for imaginative thinking and purposeful action. . And it was the necessity for this action that demanded the talents and skills of men with inventive minds and trained in the expertise of the social sciences as well as the law. Mere managers or caretakers would no longer satisfy the demands made upon the American government. 20

So after cloaking his new administration with a traditional facade in the appointments of his Cabinet, Roosevelt, through Moley, ${ }^{21}$ mobilized the intellectuals and "men of vision" for suggestions on specific policy 
strategies to cope with the numerous problems in agriculture, industry, and finance. The call for help also went out to the institutes, which, since the Twenties, had performed invaluable research tasks for the government. In January of 1933 Roosevelt wrote to Harold Moulton, director of the Brookings Institution: "quite frankly, we need help. Because I know of the splendid work that has been done by you and the Institute, and because of my old friendship for Mr. Brookings, I am hoping that you will be able to give us assistance in the preparation of a fairly definite plan between now and early March." 22

From his quarters in the Carlton Hotel preceding the inauguration, and from his offices in the State Department, thereafter, Moley sorted through the memoranda on policy directives sent Roosevelt and interviewed specialists to staff the administration. The general approach to future economic policy, which would stipulate moderate planning and experimentation, was largely set by Moley, Tugwe11, and Berle previous to the inauguration, and the specific counsel sought was molded to these lines. In the view of William E. Leuchtenburg, "by the time Roosevelt took office, he and his advisors had developed or familizarized themselves with a body of theory a good deal more coherent than is commonly suggested." 23 Convinced that "organized social intelligence" was the lever by which society could be understood, and then subsequently shaped to a positive advantage, the New Dealers began work to overhaul the badly depressed economy.

The first hundred days legislation illustrated the political intellectual mesh which characterized Roosevelt's administration. The enactment of the Agricultural Adjustment Act (AAA) set the tone for 
agricultural economics which, on the federal level, was promoted by skilled economists and lawyers. ${ }^{24}$ M. L. Wilson, an economist from Montana State College and member of The Bureau of Agricultural Economics during the Twenties, impressed Tugwell and Moley with his plan to limit farm production by domestic allotment. In the new administration he was retained as chief of the Wheat Division of the Department of Agriculture. Together with Wallace, Tugwe11, and a group of economists and legal experts, ${ }^{*}$ Wilson played a major role in shaping agricultural policy which, initially capstoned by the AAA, regulated farm production through controls on marketing and processing. With his influence over the Bureau of Agriculutral Economics already established in the Department, Wilson utilized the Bureau for the coordination of research and policymaking which was vital to the successful enactment of the AAA. As one historian comments:

The Bureau provided support for the AAA. . . and it had ties with other agencies as well, since many of the Bureau's staffs were transferred to planning positions throughout the Department. . . . The Bureau also undertook sociological studies to determine the best means of

*Members of the liberal contingent in the Department of Agricultural included: Mordecai Ezekiel, an economic advisor; William I. Myers, former Professor of Farm Finance at Cornell, the chief author of the Farm Mortgage Act; Herman Okiphant, former professor of Law at John Hopkins; Gardiner C. Means, professor of Finance at Columbia; Louis Bean of the staff of Bureau of Agricultural Economics; Howard E. Babcock, former professor of Marketing at Cornell; Adiai Stevenson, legal advisor from Chicago Law; Thurmond Arnold and Abe Fortas from Yale Law School; Alger Hiss, Lee Pressman, John Abt, Nathan Witt from Harvard Law, and Jerome Frank, lawyer and author of the brilliant study Law and the Modern Mind, served as the General Counsel. Unofficial observor, The New Dealers (New York, 1934), pp. 74-104. 
inducing farmers to participate in the Department's programs under AAA. . . , and this led to further provisions for the kind of federal-state-local community cooperation that had been encouraged by the Department of Agriculture since its first connections with the land grant colleges and extension services. These sociological studies were later supplemented by a series of attitude and opinion surveys conducted by a unit especially organized for this work, the Division of Program survey headed by Rensis likert, the first such unit to be established in any government agency. 25

The crisis in both industry and finance called for immediate remedial action on the federal level. Mobilizing experts in the Treasury Department, such as 0. M. W. Sprague, former professor of Banking and Finance at Harvard (specialist Assistant to the Secretary), James H. Rogers, professor of Political Economy at Yale (a currency specialist and consultant to Treasury), George F. Warren, professor of Farm Management at Cornell (a comodity dollar specialist and consultant to Treasury), and Dean Acheson, a legalist under Louis Brandeis (Under Secretary of the Treasury), Roosevelt organized a talented team from which he solicited advice. ${ }^{26}$ These men were selected for their expertise as well as their distance from wall street financial circles which had proved incapable of meeting the economic crisis. Initially, Roosevelt relied on Warren and Rogers, who had recently published the study, America Weighs Her Gold, for a monetary policy to raise the deflated dollar. Warren's theory argued that the principal reason for the prolonged nature of the depression was chiefly because of the government's failure to purchase gold which would have raised the value of the commodity dollar and general price level. Convinced of the plausibility of Warren's thesis (which was supported by Rogers), Roosevelt engaged in the price fixing of gold on a day-to-day basis for several weeks. The experiment did little to solve the financial dilemma, but 
it did illustrate Roosevelt's willingness to seek advice from his academic experts.

To provide some semblance of sound financial stability in his administration, Roosevelt chose Lewis Doublas who had made his mark in Congress as a young but determined budget-balancer. The Economy $B i 11^{27}$ of Roosevelt's first Congress was largely the handiwork of Douglas. Though it was Douglas' triumph in that it drastically cut the federal budget, its enactment was also a victory for Roosevelt. Cloaked with orthodox financial policy, the measure brought to its support the "tory" factions who might otherwise have opposed its provision to grant Roosevelt wide discretionary powers. The measure satisfied the conservative opposition and bought Roosevelt time to formulate an inflationary policy which would promote recovery on a more widespread bas is than the Warren-Rogers scheme.

Administrative planning for industrial recovery brought to the federal government still another group of high-level theorists. 28 What eventually became the National Industrial Recovery Act (NIRA) emerged from a series of debates and compromises carried on in the advisory councils of the Executive office. Efforts to devise a plan employing broad cooperation with the business community centered around the office of Moley who, while officially serving as the Assistant Secretary of State, became the "unofficial" clearinghouse for industrial recovery plans. He seriously investigated the problem, calling upon the Brookings Institution for advice, and enlisting the aid of General Hugh Johnson whose experience on the War Industries Board during World War I served as a comparable project for precedent as well as 
enlightenment. The NIRA resulted chiefly from these discussions attended by such personnel as Tugwell; Moley; Harold Moulton, a Brookings Institution economist; David Podell and Gilbert Montague, trade association lawyers; W. Jett Louk, Iabor economist; Donald Richberg, labor lawyer; General Hugh Johnson; and Frances Perkins among others. Ellis Hawley, historian of the NIRA, writes:

The final version contained something for nearly all of its principal authors. The authority to formulate codes of fair competition satisfied the business planners. Section 7A, with its promise of collective bargaining and minimum labor standards, made the measure attractive to the trade unions and social workers. The provision for federal licensing gave some hope for national economic planning. And a $\$ 3,3000,000,000$ public work $\$$ program appealed to the spenders and pump primers.

As illustrated by the enactment of the NIRA, business and industry were viewed in a partnership with government to reverse the economic trends of the depression. The financial community, however, warranted no such standing with federal policy-makers under Roosevelt who insisted that the financiers be disciplined. ${ }^{30}$ with the legal advice of James Landis, professor of Legislation at Harvard Law School, and Thomas Corcoran and Benjamin Cohen, brilliant young Harvard Law graduates, the Administration produced first the Securities Act of 1933, and 1ater the more comprehensive measure, the Securities Exchange Act of 1934. Reporting and disclosure requirements were made in order to regulate trading practices and to eliminate the possibility of inside manipulation-a practice which had been disclosed in the Pecora Hearings on the stock market and banking community. 31

Regional planning, a long standing concern with the federal government, received a strong endorsement from Roosevelt when, in the 
midst of the hundred days legislative activity, he signed the Tennessee Valley Authority (TVA) legislation. ${ }^{32}$ Heavily influenced by Arthur E. Morgan, an engineer who had designed the Miami Conservancy District for flood control prior to World War I, and more recently the President of Antioch College in Ohio during the Twenties, Roosevelt opted for a multipurpose appraoch for the regional control of the Tennessee Valley. His scheme, combining social and physical pranning, went far beyond the long-standing federal debate over the concerns of power and fertilizer production. The provisions of the TVA were far-reaching and novel by any previous federal standards, As a corporation, the TVA was "clothed with the power of a government but possessed of the flexibility and initiative of a private enterprise." 33 Section 23 of the Act summarizes its broad implications"

... for the especial purpose of bringing about in said Tennessee drainage basin and adjoining territory. . . (1) the maximum amount of flood control; (2) the maximum development. . . for navigation purposes; (3) the maximum generation of electric power consistent with flood control and navigation; (4) the proper use of marginal lands; (5) the proper method of reforestation. . and (6) the economic and social well-being of the people living in said river basin. 35

These legislative enactments illustrate the principal administrative achievements of Roosevelt's first hundred days in office. Out of these laws came a proliferation of alphabetic agencies which were provided for, under law, to administer the newly enacted measures. To head these agencies Roosevelt turned to a new group of men whose supervisory talents were needed to put the brain-children of the intellectuals into operation. Of these men Charles E, Jacobs observes: 
This second skill group was made up of those either trained in, or naturally adept at the task of management and organization on a small scale. These supervisory types, or "bosses," were responsible for getting the grand programs thought up by these brain trusters and enacted by Congress--implemented into reality. And al though as a general class of administrators, their intellects may have been less sparkling than those of the Tugwells, Corcorans and Berles, the mission they were called upon to perform was equally important and therefore just as valuable. 35

The very nature of these New Deal experiments, enacted during a high point in Roosevelt's popularity, demanded "imaginative but cautious" administrators. Therefore, in order to withstand the criticisms and objections that would undoubtedly arise with the implementation of his unprecendented programs, Roosevelt mobilized a group of "sharp-eyed supervisors."

The new public works program was an example of the type of legislation which required an administrator of this caliber. ${ }^{36}$ "Honest Harold" Ickes, Secretary of the Interior, possessed these qualities in abundance. Title II of the NIRA provided for a Public Works Administration (PWA) to initiate construction projects directly and to allot loans and matching federal grants to states and other public entities to promote wide-scale construction. Ickes held tightly to the purse strings of his $\$ 3.3$ billion appropriation, and, as Arthur Schlesinger, Jr. surmises, "read every line of everything and often fired documents back with demands for revision. . . Ickes meanwhile called on PWA employees to report on each other, denounced them for coming late to work or taking too long for coffee, and even issued an edict against pulling down shades over the windows in office doors." 37 Although it has been argued that Ickes failed in his economic 
function of producing wide-scale employment at a fast pace, ${ }^{38}$ he did fulfill Roosevelt's need for an administrator who could both develop an organization and keep its channels free from corruption.

Working in close proximity to Ickes were Harry Hopkins, Federal Emergency Relief Act (FERA) administrator, and General Hugh Johnson, National Recovery Act (NRA) administrator. In charge of doling out relief, Hopkins managed to direct a large proportion of the funds for work relief--assigning unemployed teachers to teaching jobs as well as providing funds to local self-help and barter associations. Due to Hopkins' amazing organizational talents, Roosevelt allocated PWA funds for an extended works relief project under his direction which became the Civil Works Administration (CWA). 39

The task facing General Hugh Johnson of implementing the fair practices codes under the NIRA proved much more cumbersome. ${ }^{40} \mathrm{His}$ administrative skills, though, developed on the War Industries Board during the first World War, served him well. With the assistance of his chief lieutenants, ${ }^{*}$ he hit the industrial strongholds of the nation by a storm, and before the end of the year held agreements from most of the major industries.

*Among the group to aid him in setting up the NRA codes, Johnson solicited the help of: Donald Richberg, labor lawyer as chief counsel to NRA; Col. Robert Lea, formerly of the War Industries Board during World War I as Assistant Administrator for Industry; Alvin Brown, Assistant Director of the Budget as Assistant Administrator of the NRA; Edward McGrady, AF of L veteran legislative agent as Assistant Administrator in charge of labor; Kenneth M. Simpson, geologist from Columbia in charge of the mining and drilling industries; William Averell Harriman, railroad magnate in charge of heavy industries; Sol Rosenblatt, Harvard Law graduate in charge of amusements and various industries; Arthur Whiteside, founder of the National Credit Bureau as head of textiles, wholesale and retail; and William Davis, legal advisor to the War Department as National Compliance Director. Unofficial observor, The New Dealers, pp. 28-74. 
There were also cases where Roosevelt based his selection of administrators more on "previous experience than on any guarantee of managerial expertise." 41 Such was the case for the appointment of Joseph P. Kennedy to head the Securities and Exchange Commission (SEC) where his contacts among the financial elite facilitated the acceptance of SEC regulations among the financial community. ${ }^{42}$ Jesse Jones, head of the Reconstruction Finance Corporation (RFC), provided a similar function. As a Texas banker and industrialist, his presence did much to abate conservative fears that the New Deal would be in the practice of handing out billions of dollars and undermining capitalism. ${ }^{43}$

Occasionally, the intellectual/administrator relationship was not characterized by harmony. As head of the AAA, George Peek alienated most of the academic and liberal faction brought into the Department of Agriculture by Roosevelt. ${ }^{44}$ Peek was an advocate of "the $01 d$ school of McNary-Haugenism which saw its mission as a single-minded devotion to the cause of raising farm prices, regardless of the effect on the rest of the nation's economy or that of the world. "45 This was an anathema to his planning conscious subordinates* who were trying to instigate far-reaching economic reforms in the agricultural sector of the economy. With the intercession of Tugwell and Wallace, Peek was removed to a less sensitive position in the administration in the State Department--a typical Rooseveltian gesture to appease both sides and what they represented. of significance in this case, though, is that the social engineers won an overwhelming victory in demanding an administrator who would support and administer the fruits of their labor. 
To direct his own creation, the TVA, Roosevelt selected men highly qualified for the job. ${ }^{46}$ For chairman of the three man board, Roosevelt appointed A. E. Morgan who proved indispensable in shaping his conceptualizations about the TVA in its planning stages. As a civil engineer and flood control expert, he was designated to carry out the dam construction projects and oversee the social and economic planning of the valley. Similarly Harcourt Morgan was chosen to administer the agricultural production due chiefly to his experiences as director of the University of Tennessee Agricultural Experiment Station during the decades since the turn of the century. And for counsel and director of the power and utilities function of TVA, Roosevelt secured David Lilienthal, one of Felix Frankfurter's protoges and former head of Wisconsin's Public Utility Commission. These appointments were hailed by the social engineers of the new administration as ones both of vision and necessity. As an experiment in broad federal intervention into the private sector, only men cognizant of the dictates of planning and research would be able to administer it to its fullest potential. And in the beginning much hope was placed in the hands of these individuals. But the appointment of A. E. Morgan as director soon created problems. ${ }^{47}$ As chief advocate and developer of the measure, his aspirations for the measure soon surpassed the provisions of the law. Subsequently a split ensued between A. E. Morgan and H. A. Morgan and Lilienthal. Analyzing the potential seriousness of the split, Roosevelt eventually replaced A. E. Morgan with Lilienthal as director of the TVA.

The passage and enactment of these measures of the first hundred days of the New Deal, while not irreversably turning the tide of the 
depression, did raise the hope of the nation far beyond the despair that had characterized it a hundred days earlier. In this the first hundred days was a success even though the measures enacted had yet to solve the economic dilemmas. Despite the talent and energy which went into this legislative effort to rectify the economy, real problems in administrative coordination persisted, at times crippling the political machinery to inaction and policy contradiction. To provide some administrative unity among a11 the alphabetic agencies created during 1933, Roosevelt, by executive order, established the National Emergency Council (NEC). ${ }^{48}$

The membership of the NEC included the administrators of all of the various agencies, the Secretaries of Interior, Commerce, Agriculture, and Labor, and Dr. Winfield Riefler, a statistician from the Central Statistical Board (CSB) to assure standard statistical reporting by all the administrative agencies. Donald Richberg, chief counsel to the NRA, was appointed as director whose function was to develop an agenda of the various subjects under discussion in preparation for the meetings. One of the initial tasks of the NEC was to provide some form of consistency among the functions of the agencies in order to prevent overlapping and contradiction. For example, the reclamation features of the TVA clearly contradicted the intentions of the crop control features of the AAA, and the NRA regulations pertaining to the timber industry adversely affected both the Federal Housing Authority (FHA) in its drive for home remodeling and the public works clearance projects of the PWA. ${ }^{49}$ The attempts at coordination through the NEC, primarily by its requirement for each executive agency to clear all legislative proposals through 
the NEC, failed chiefly by the repeated resistance of the newer agencies to coordinate. The coordination of activities would have necessitated compromise which during the emergency would have jeopardized the flexibility needed to meet the economic crisis. If anything, the NEC provided a meeting place for the airing of cross-agency conflicts and administrative shortcomings. In this function, it was a "school for policy-makers, giving some structure to the range of programs that resisted formalization. The educative experience by any pragmatic test paid off. For all of its administrative untidiness, the New Deal hammered through new structural changes. "50 For the newly emerging political elite, this training in administrative management, provided by the NEC, served as an invaluable lesson in political survival. And for Roosevelt, the NEC clearly demonstrated the need for a permanent solution to the organizationl dilemmas of the executive branch, which with the additions of the new agencies, had expanded to unmanageable proportions.

As the previous pages reveal, during Roosevelt's first year in office, a group of social scientists and legalists, as well as professional administrators converged in Washington to chart the path back to recovery. These men, as 111 ustrated, were carefully compartmentalized into various departments and agencies to advise, and at times direct administrative policy. And, typical of bureaucratic rivalry, their influence was most often narrowly confined to the offices they served. Although the NEC did little to consolidate their efforts, at least one experiment of the New Deal, free from departmental or agency responsibility, did-- 
the National Resource Committee (NRC).*

The NRC was established as an advisory committee for the various agencies created under the NIRA. ${ }^{51}$ Its membership included: Frederic Delano, uncle of the President, a trustee of the Brookings Institution and activist in city and regional planning; Charles Merriam, founder and director of the Social Science Research Council (SSRC) and member of the staff of the Recent Social Trends Committee; Wesley Mitchell, of the National Bureau of Economic Research (NBER); Beardsley Ruml, Dean of Social Sciences at the University of Chicago; and Henry Dennison and Thomas Yantis, industrialists dedicated to the objectives of planning based on research. After the NIRA advisory boards were reorganized in 1934, the NRC was made into an advisory comittee with active charge of its own program. Although much of the work of its early years dealt with coordination in the development of natural resources and conservation at the request of Roosevelt, the NRC, nevertheless, managed to establish a limited social science clearinghouse in the federal government due chiefly thorugh the NRC's ties with the institutes via Merriam, Delano, Mitchell, and Ruml. Relying on the staffs of the various institutes for much of their technical and research work, the NRC continually demonstrated throughout the Thirties the need for social science intelligence gathering as an instrument for policy-making. The institutes provided the analyses, and Delano and Merriam, who had easy access to the President, aired the findings to the administration. Among some of the studies undertaken during the depression by the institutes were: housing, medicine, health, effects of the depression Board.

*The original title of the NRC was The National Resources Planning 
on the nation, business cycles, crime, ${ }^{52}$ and, more notably, the Brookings series on NRA by Leverett S. Lyons and on AAA by Edwin G. Nourse. ${ }^{53}$ Although Roosevelt at times disagreed with the findings, he recognized the need for federal access to research. ${ }^{54}$ It was within the ranks of the NEC that Roosevelt first commissioned a study on the reorganization of the executive branch to provide some coherency in executive policy necessitated by the growing responsibility of the federal government.

If the Twenties provided an apprenticeship for this emerging political elite of academics, legalists, and public administrators, then the initial two years of the New Deal provided them with the political skills to advance through journeyman stages. Although disharmony and disagreement often characterized this new mobilization, it was mare in tactic than in strategy. All agreed that the utilization of social intelligence could alter the despair that symbolized the status quo, and all were at work to chart this new course to recovery. Tempered by the shortcomings of this initial effort, and encouraged by the endorsement of the 1934 elections, this fledging political elite sought new methods to solve the still persistent economic crisis.

By the time the 74 th Congress convened in Washington in the fall of 1934, Raymond Moley, a member and organizer of the original brain trust, had become a casualty of the new regime. ${ }^{55}$ As a political appointee in the State Department, Moley was not able to escape the running battle between the political appointees and the career diplomats. And as a member of the delegation at the London Economic Conference, he performed "the unpardonable indiscretion of comnitting to a cablegram a frank 
analysis of the delegation. " 56 Therefore, he officially resigned in September of 1933, but, as a private citizen working out of Columbia, he continued to offer advice to the administration. The resignation of Moley underlined the political adaptability required to serve the federal government in the days before administrative assistants were allowed the president. And although "conservatives of various stripes gleefully proclaimed the disintegration of the celebrated brain trust, and hopefully forecast a retreat from the innovations of the New Deal, 157 no such occurance took place. By the time Moley left office, the new elite of academics and professionals had become an established fixture in federal politics.

During the second hundred days legislative period, Roosevelt moved from the initiation of primarily emergency and relief measures to the incorporation of reform bills aimed at promoting recovery through the a) teration of existing abuses in the system. ${ }^{58}$ After the Schechter Decision of the Supreme Court invalidated the NIRA ${ }^{59}$ in early 1935, Roosevelt pushed for major changes in the existing banking, tax, and holding company laws as well as the enactment of social security legislation.

Summoning his advisers from the Treasury Department, Roosevelt called for a reassessment of the tax laws..$^{60}$ The drafting session included Herman 01 iphant, general counsel to Treasury and long time associate and follower of Louis Brandeis; Raymond Moley, down from Columbia on special assignment; Felix Frankfurter, from the Harvard Law faculty, and members of the Treasury staff. ${ }^{*}$ The resultant measure aimed at

*See page 78 of this chapter for a discussion of the personnel staffing the Treasury Department. 
distributing more evenly the national income by the incorporation of a graduated income tax imposing greater taxes on high private and corporate incomes and profits. After congressional debate and approval, the Wealth Tax Act of 1935 adopted the provisions of increased gift and capital stock taxes, the initiation of the excise profits taxes, and the levying of a steep surtax. Although the measure did little to redistribute income during the Thirites, it established the precedent for the utilization of tax policy as an instrument of social policy, and in this respect was at least a limited victory for the social engineers.

During this congressional session of 1935, Roosevelt also recommended an extensive consideration of his social security measure. ${ }^{61}$ For Roosevelt, the origins of his idea for a social insurance program were deep-rooted. As governor of New York, he had investigated the possibilities for such a program, but saw no fruition in his endeavors. ${ }^{62}$ In the summer of 1934, Roosevelt convened the Committee on Economic Security under the Teadership of Frances Perkins to draft a measure of social insurance suitable to the needs of the nation.* The Committee approved a program of contributory old-age insurance and unemployment compensation patterned

*The formal membership of the Committee included: the Secretaries of Labor, Agriculture, Treasury, Justice, and Harry Hopkins, administrator of the relief program. Other personnel involved in the Committee's work were: Professor Edwin Witte of the University of Wisconsin, research director in charge of technical assistance which included economists, analysts, lawyers, clerical, and statistical experts from every executive department; Isador Lubin, chief economic advisor; Katherine Lenroot, head of the Children's Bureau as chief social analyst; and Tom Eliot, assistant solicitor of the Department of Labor as chief legal advisor. Two experts-Andre Tixier and Oswald Stein who had studied every welfare system in the world-were called in for advising. Frances Perkins, The Roosevelt I Knew (New York, 1946), pp. 287-292, 
after the Wisconsin plan which provided for a joint federal-state system of supplying aid to the unemployed. Congress passed the Conmittee's proposal with minimal opposition, and on August 15, 1935 the Social Security Administration was established. The Act created a compulsory old-age insurance program whereby workers, at the age of sixty-five, received retirement benefits financed by taxes on their wages and on their employer's payroll tax. A special provision also set up a program of compensation to the unemployed, dependent mothers and children, the handicapped, and those aged not covered by Social Security. To organize and direct this system, ${ }^{63}$ Roosevelt called upon Henry Seidemann of the Brookings Institution who had previously designed the accounting and control system for payroll taxes and benefit payments for the Committee on Economic Security. With the full enactment of the Social Security measure, the United States became a welfare state, based both on capitalism and federal responsibility to the social and economic we 11 -being of its citizenry. 64

The second hundred days also produced a measure precipitating the abolition of holding companies which controlled utility monopolies. 65 Benjamin Cohen and Thomas Corcoran, legal advisors and principal drafters of the SEC, introduced a piece of legislation for the Administration to eliminate the holding company empires that "fleeced the consumer, corrupted legislatures, and, by their elusive operation, evaded state regulation." 66 The Public Utilities Holding Company Act of 1935, which resulted from Cohen and Corcoran's efforts, eliminated all holding companies twice removed, and authorized the SEC to compel the registration of all existing holding companies in order to supervise all financial 
transactions. By means of this enactment, the Rural Electrification Administration (REA) was able to produce cheap electricity to four out of every ten American farms. ${ }^{67}$

The banking bill of the 74th Congress originated chiefly through the efforts of Marriner Eccles whom Roosevelt had appointed to the Federal Reserve Board. ${ }^{68}$ As a result of his experiences on the Board, Eccles, himself a banker from Utah, felt that the Federal Reserve System only served the interests of the banking community rather than the nation at large. To promote recovery, Eccles urged a reorganization of the System where the monetary mechanism could be used to secure business stability through conscious control and management. The Banking Act of $1935^{69}$ established many of Eccles proposals and centered the authority of the Federal Reserve system in the Board of Governors which provided for a national standardization of rediscount rates and reserve requirements-the mainstays of currency and credit. And, by requiring all existing institutions to join the Federal Reserve system by 1942, the Act established the framework for stronger monetary policy on the federal lever.

These enactments of the second hundred days firmly established the foundations of the New Deal which provided the nation with a welfare state based on the dictates of capitalism and the federal supervision and instigation of social and economic policy. Except for the passage in the later New Deal years of the Soil Conservation and Domestic Allotment Act, ${ }^{70}$ and the Fair Labor Standards Act, ${ }^{71}$ the domestic New Deal remained virtually unchanged during Roosevelt's succeeding administrations. 
This New Deal experiment, chiefly written by the newly mobilized elite in Washington, created the framework for federal stabilization of the economic and social forces of the nation. In many ways, the programs fell short of achieving a return to the prosperity of the previous decade, but that the federal government assumed the responsibility of the nation's leadership ushered in a new age in American history. This new era in federal policy, based on the precepts of social knowledge and the new methods in social science paved the way for the possibility of a more stabilized economic and social environment in the United States. This experiment, started in the Thirties, would reach maturity in later decades.

The stimulus for this experiment in national economic recovery came chiefly from the personnel schooled in the universities and institutes of social planning which had demonstrated the need for social intelligence to direct policy-and decision-making on the federal level. By recruiting these men and those of the older elite who shared similar sentiments, * Roosevelt gave them an active role in the creation of federal policies. And by recommending the policies and views of this elite into political reality, Roosevelt played a significant role in shaping the contours of a new elite in Washington. By 1935, national policies revolved around the newly created welfare state which significantly altered the responsibilities of the federal government. This new state, a political reality in 1935, having evolved from Progressive aspirations and the work of Roosevelt's extended brain trust,

*Personnel of the older, established elite who were assimilated into the new mobilization were men such as Dean Acheson, Averell Harriman, and Joseph P. Kennedy. 
demanded administrative supervision dedicated to the utilization of social research and planning as instruments of federal policy to ensure the perpetuation of the welfare state in the modern era. Therefore, before he turned from domestic to international policy, Roosevelt called upon his new political elite for assistance in the reorganization of the executive branch of government which, if realized, would promote and secure a viable continuation of the positive state. 


\section{ENDNOTES}

1 See William E. Leuchtenberg, Franklin D. Roosevelt and the New Deal (New York, 1963), pp. 41-42; Arthur M. Schlesinger, Jr., The Coming of the New Deal (New York, 1959), pp. 1-5; Frank Freide T, Franklin D. Roosevelt: Iaunching the New Deal (Boston, 1973), pp. 196-212.

${ }^{2}$ Samuel I. Rosenman, ed., The Public Papers and Addresses of Franklin Roosevelt (13 vols., New York, 1938-50), II, p. 11.

${ }^{3}$ For an analysis of Roosevelt's early political career see: Frank Freidel, Franklin D. Roosevelt: The Apprenticeship (Boston, 1952); Frank Freidel, FrankTin D. RooseveTt: The Ordeal (Boston, 1954); Frank Freidel, Franklin D. Roosevelt: The Triumph (Boston, 1956); Bernard Bellush, Franklin Roosevelt as Governor of New York (Wew York, 1955).

${ }^{4}$ Bellush, Franklin Roosevelt as Governor of New York, pp. 58-243.

${ }^{5}$ See Ibid., pp. 295, 297-298, 301, 304, 312 for 1ists of the staffs of several cormissions and comittees called by Roosevelt during his tenure as governor.

${ }^{6}$ Samuel I. Rosenman, Working with Roosevelt (New York, 1952), p. 59.

7 Ibid. , p. 59

${ }^{8}$ Daniel R. Fusfield, The Economic Thought of Franklin D. Roosevelt and the Origins of the New Deal (New York, 1956), p. 279.

9 leuchtenberg, Franklin D. Roosevelt and the New Deal, p. 33. See a) so Dixon Wecter, The Age of the Great Depression (New York, 1948), pp. 58-59; Herbert Croty, The Promise of American I ife (New York, 1909), pp. 100-175; John Dewey, Intelligence in the Modern World (New York, 1928), pp. $435-455$.

${ }^{10}$ Quoted in Leuchtenberg, Franklin D. Roosevelt and the New Deal, p. 34. The referent is Thorstein Veblen.

11 See James A. Farley, Behind the Ballots (New YOrk, 1958) and Roy Peeland and Thomas Donnelity, The 1932 Campaign (New York, 1935) for a comprehensive history of the 1932 campaign.

${ }^{12}$ Rosenman, Working with Rooseve1t, p. 85.

${ }^{13}$ Ibid., pp. 85-86. 
${ }^{14}$ Rexford Tugwe 11, The Brains Trust (New York, 1968), pp. 267529; Raymond Moley, After Seven Years (New York, 1939), pp. 35-66.

15 Rosenman, Working with Roosevelt, pp. 56-92; Freidel, Frankl in D. Roosevelt: Launching the New Deal, pp. 60-82; Moley, After Seven Years, pp. 67-148; Rexford Tugwe17, The Democratic Roosevelt (New York, 1957), pp. 249-269. pp. 8-9.

16 "The Hullabaloo over the Brain Trust," Literary Digest, XVI (1933),

17 For a thorough depiction of the selection of Roosevelt's first Cabinet, see Charles Hurd, When the New Deal was Young and Gay (New York, 1965), pp. 91-102; Moley, After Seven Years, pp. II1-131. 1972), p. 240.

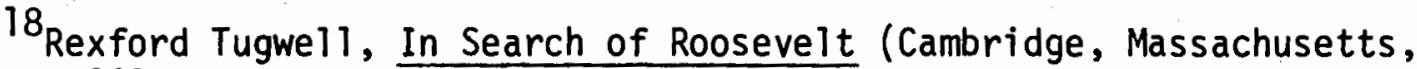

19 Ibid., p. 244.

${ }^{20}$ Charles E. Jacobs, "Administrative Leadership: Challenge and Response," in Charles E. Jacobs, ed., Leadership in the New Deal (Englewood Cliffs, New Jersey, 1967), p. 3.

${ }^{21}$ Moley, After Seven Years, pp. 84-138.

${ }^{22}$ Quoted in Charles B. Saunders, The Brookings Institution: A Fifty Year History (Washington, D. C., T966), p. 53.

23 Leuchtenberg, Franklin D. Roosevelt and the New Deal, p. 33.

${ }^{24}$ See Richard S. Kirkendall, Social Scientists and Farm Politics in the Age of Roosevelt (Columbia, Missouri, 1966), pp. 50-169 for a discussion of the AAA.

${ }^{25}$ Gene M. Lyons, The Uneasy Partnership (New York, 1969), p. 61.

${ }^{26}$ For a discussion of Roosevelt's financial advisers see Unofficial Observer, The New Dealers (New York, 1934), pp. 104-141.

${ }^{27}$ Freidel, Frankl in D. Roosevelt: Launching the New Deal, pp. 247253; Schlesinger, Jr, , The Coming of the New Deal, Pp. 10-14.

${ }^{28}$ See Ell is W. Hawley, The New Deal and the Problem of Monopoly (Princeton, 1966), pp. 18-22 for a discussion of the industriat planners.

${ }^{29}$ Ibid., p. 22.

30 Jacobs, "Administrative Challenge and Response," p. 6.

${ }^{37}$ For an indepth study of the Pecora hearings see Ferdinand Pecora, Wall Street Under Oath (New York, 1939). 
${ }^{32}$ Preston J. Hubbard, Origins of the TVA (Nashville, 1961), pp. 194-315.

${ }^{33}$ Gordon R. Clapp, The TVA: An Approach to the Development of a Region (Chicago, 1955), p. 8 .

${ }^{34}$ Quoted in Ibid., pp. 8-9.

${ }^{35}$ Jacobs, "Administrative Challenge and Response," p. 6.

${ }^{36}$ Leuchtenburg, Franklin D. Roosevelt and the New Deal, pp. 133-134.

${ }^{37}$ Schlesinger, Jr., The Coming of the New Deal, pp. 285-286.

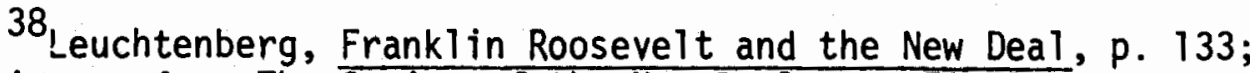
Schlesinger, Jr., The Coming of the New Deal, pp. 70-71.

${ }^{39}$ Schlesinger, Jr., The Coming of the New Deal, pp. 267-273.

${ }^{40}$ See Hugh S. Johnson, The Blue Eagle from Egg to Earth (New York, 1935) for a descriptive account of the enactment of TitTe I of the NIRA.

${ }^{41}$ Jacobs, "Administrative Challenge and Response," p. 8.

42 Ibid. , p. 9.

43 "Jesse Jones," Fortune Magazine, XVI (1940), pp. 140-144.

44 Kirkendall, Social Scientists and Farm Politics in the Age of Roosevelt, pp. 169-185; and Leuchtenberg, Franklin Roosevelt and the New Dea I, pp. 75-77.

${ }^{45}$ Jacobs, "Administrative Challenge and Response," p. 14.

"46 Jonathan Daniels, "Three Men in a Valley," New Republic, LXXXXVI (1938), pp. 34-37.

${ }^{47}$ Schlesinger, Jr., The Coming of the New Deal, pp. 330-338; Willson Whitman, "Morgan and Morgan and Lilentha?," Harper's, 177 (Sept. 1938), pp. 352-361; J. C. Poe, "The Morgan-Ii Nation, CX! II I (1936), pp. 385-856.

${ }^{48}$ The following discussion of the NEC is taken from Lester G. Seligman and Elmer E. Cornwall, Jr., eds., The New Deal Mosaic, pp. xiii-xxix.

${ }^{49}$ Ibid. , p. $x \times i$.

${ }^{50}$ Ibid., p. xxviii.

${ }^{51}$ The following section on the NRC is taken largely from Lyons, The Uneasy Partnership, pp. 64-74. 
52 Ibid., pp. 66-67.

${ }^{53}$ Saunders, The Brookings Institution: A Fifty Year History, pp. 54-57.

54

Ibid., p. 56.

${ }^{55}$ Moley, After Seven Years, pp. 275-280.

56 Ernest K. Lindley, "The Roosevelt Revolution" in Charles E. Jacobs, ed., Leadership in the New Deal (Englewood Cliffs, New Jersey, 1967), p. 37.

${ }^{57}$ Ibid., p. 37.

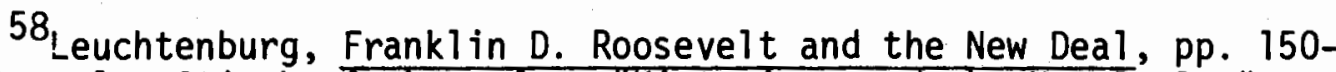

151 ; See also 0tis 1. Graham, Jr., "Historians and the New Deals," The Social Studies, LIV (1963), pp. 133-140 for an historiographical study of the profession's opinions on the two New Deals.

${ }^{59}$ See: Hawley, The New Deal and the Problem of Monopoly, pp. 130146 for a discussion of the unconstitutionality of the NIRA as stipulated by the Schechter Decision.

60 Leuchtenberg, Franklin Roosevelt and the New Deal, pp. 152-154; Arthur M. Schlesinger, Jr., The Politics of Upheaval (Cambridge, Massachusetts, 1960), pp. 325-335.

${ }^{61}$ See Frances Perkins, The Roosevelt I Knew (New York, 1946), pp. 278301; Alvin David, "01d-Age, Survivors, and Disabil ity Insurance:

Twenty-Five Years of Progress," Industrial and Labor Relations Review, XIV (1960), pp. 9-22. 190.

62 Bellush, Franklin D. Roosevelt as Governor of New York, pp. 175-

${ }^{63}$ Saunders, Jr., The Brookings Institution: A Fifty Year History, pp. 58-59.

${ }^{64}$ Paut K. Conkin, FDR and the Origins of the Welfare State (New York, 1967), pp. 50-54.

${ }^{65}$ John BTum, From the Morgenthan Diaries (Boston, 1959), pp. 298302; Moley, After Seven Years, pp. 307-314.

66 Leuchtenberg, Frankl in Roosevelt and the New Deal, p. 154.

67 Ibid., p. 157.

${ }^{68}$ For an understanding of Eccles' economic philosophy, see: "Marriner Stoddard Eccles," Fortune, XI (1935), pp. 63-64; Marriner Eccles, Beckoning Frontiers (New York, 1951), pp. 160-195. 
${ }^{69}$ F. A. Bradford, "The Banking Act of 1935," American Economic Review, XXV (1935), pp. 661-672.

70 Leuchtenburg, Franklin D. Roosevelt and the New Deal, pp. 172-174; Schlesinger, Jr., The Politics of Upheaval, p. 504.

${ }^{71}$ Ibid., (respectively), pp. 263-264; pp. 519-520. 


\section{CHAPTER VI}

THE REORGANIZATION OF THE FEDERAL GOVERNMENT AND THE CIRCULATION OF THE NEW ELITE

When Franklin Roosevelt gave Charles Merriam of the National Resource Committee (NRC) executive approval in early 1936 to focus on the problem of executive reorganization, ${ }^{1}$ the intellectual elite of experts and social science orientated academics had already become an established part of the federal bureaucracy. As illustrated in the previous chapter, this new elite was largely responsible for the creation of federal policy which enlarged the responsibilities of the national government from regulator to guarantor of the interdependent social and economic sectors of American society. By 1936 the focus of federal policy was clearly evident, as was the completion of the circulation of the new elite which had fostered this new role for the national government. Consistent with the elitist perspective in the United States, the evolution of both this elite and the enlarged role of the federal government was gradual and non-violent. The process took the greater part of two deacdes to evolve and become an integral facet of the American system. Once the framework of this new organization of personnel and policy was realized, a reorganization, involving the structure and function of the administrative branch of the federal government was necessary to promote a viable leadership to direct and perpetuate the fledgling welfare state. Robert: Michels, almost a century earlier, had observed this tendency of the leadership class to develop a structured 
and well-defined executive body in all large organizations. ${ }^{2}$ And such was the case for the New Dealers in 1936. With the move to reorganize the executive branch in 1936, Roosevelt sought to secure a leadership capable of administering the positive welfare state, and supervising its continuance into the future.

By moving to reorganize the executive department in 1936, Roosevelt not only recognized the need for restructuring the administrative network vastly complicated by the influx of New Deal agencies, but also continued almost a century's work on executive administrative reform. ${ }^{3}$ The history of the concerted efforts for reorganization dates to the post-bellum period of the Civil War when congressional investigative committees analyzed the administrative structure in an attempt to establish an executive branch streamlined to the needs of the legislature and to the exigencies of the economy. ${ }^{4}$ These efforts failed to formulate the necessary legislation for reorganization as neither the inquiry nor the intent received presidential sanction. It was not until 1905 when Theodore Roosevelt appointed the Keep Commission to study executive administration that responsibility for reorganization transferred from the congressional to executive branches and set the precedent for the executive branch to oversee $i$ ts own operations. ${ }^{5}$ This transference of reorganizational initiative significantly altered the nature of the intended reform. The major congressional assumptions underlying reorganization in the nineteenth century held that economy based upon efficient method would result in effective government produced by a minimal capital expenditure, On the other hand, the executive stance gave efficiency a co-equal status with economy insisting that the method 
of expenditure was as important as the amount expended. ${ }^{6}$ These two concepts, "economy and efficiency," preoccupied the advocates of reorganization throughout the initial decades of the twentieth century when the principle of scientific management guided the mechanics of all large organizations--including government. ${ }^{7}$

The first enactments of executive reorganizations came from the administrations of William Taft and Woodrow Wilson. ${ }^{8}$ Taft, on the basis of the recommendations from his Commission on Economy and Efficiency,* sequestered from Congress authority to bring about needed transfers among the executive agencies, ${ }^{9}$ Wilson pursued a similar course. By the authorizations stipulated by the Overman Act of 1917, reflecting the wartime emergency of World War I, Wilson received broad powers to redistribute the functions of executive agencies. ${ }^{10}$ Although these authorizations established the beginnings of executive reorganization, they niggardly reflected the intentions of the Commission on Economy and Efficiency which greatly influenced both Taft and Wilson. ${ }^{11}$ Budgetary programs were still non-existent in the federal government where all monetary transactions, in terms of appropriations and expenditures, were controlled by Congress. To the Commission, the existing system lacked the prerequisites needed for effective administration, and recommended the immediate enactment of a budgetary system. Taft and Wilson promoted its implementation, but Congress stood steadfast in objection.

*Taft commissioned prominent political scientists to staff his Commission on Economy and Efficiency. Its membership included: Frederick A. Cleveland, Director, New York Bureau of Municipal Research; W. F. Willoughby, Director, Institute for Government Research; W. W. Warwick, Frank Goodnow, Henry Chase, Merritt 0. Chance, all eminent political scientists. Rexford Tugwe11, The Enlargement of the Presidency (New York, 1960), p. 398. 
The widescale expenditures of the First World War drastically weakened congressional opposition. When the war was over, the incurred debts and the burdens of increased tax payments proved too cumbersome for congressional suprevision. Therefore, in order to ensure economy and efficiency in the handling of financial transactions, Congress passed the Budget and Accounting Act of 1921 which created the Bureau of the Budget and the Office of the Comptroller. ${ }^{12}$ With the enactment of this piece of legislation, budgetary policy became an effective tool of administration in the federal government. Congress, however, did not relinquish all of its former power over financial concerns to the executive branch. As one historian notes:

. . The Comptroller General would become a serious limitation on the presidential power. . . . It was a good principle that Congress should scrutinize Executive performance; and the Comptroller General was thus made an officer responsible to the Congress, with the duty of reporting on the use of appropriated funds. What was not expected was that the . enormous power of an irremovable official would be used to establish a system of pre-audits which, in effect, could seriously limit the President's constitutional duty to see that the laws were faithfully executed. McCarl, the first Comptroller General, took it upon himself to say what might or might not be done with appropriated funds. He demanded to be satisfied with the Executive's intentions and would approve no warrants until he looked into the elaborate submissions he demanded. 13

Although the Twenties provided negligible additions to the scope of executive reorganization, the implementations of the Budget and Accounting Act of 1921 provided for a more coherent management of federal finances, and in this manner enlarged presidential control of the departments and agencies of the executive branch. ${ }^{14}$ The Bureau of the Budget, housed in the Treasury Department, was made clearly subordinate to the President, and its Director was made responsible to him by the provisions 
of the law. The chief function of the Bureau was to formulate a financial plan for the current year based upon presidential policy and estimates from the budget officers serving each executive department or agency. In this regard, the President exercised a greater control over the departments under his supervision as the Director of the Budget recorded all department operations requiring funding, and provided the President with a blueprint of all administrative modifications and changes. At times the Comptroller General hindered the execution of presidential policy, but at least the chief executive was afforded the advantage of a semi-cohesive instrument of administration via the Bureau of the Budget.

By the time Franklin Roosevelt assumed office in the Spring of 1933, the administrative network of the executive branch had chiefly the same structure as that of 1921 save for the additions of a few executive agencies like the Reconstruction Finance Corporation (RFC) and the Federal Farm Board (FFB). Roosevelt had a long time interest in the advantages of administrative reform. During his tenure as Governor of New York, he staunchly supported the ideals of executive reorganization. ${ }^{15}$ As President, Roosevelt envisioned reorganization as primarily an efficiency measure with little economy to be expected. In this appraisal of reorganization, he made a significant break with his predecessors who saw reorganization as a means to cut the federal budget as well as a provision for efficient government. On the subject of administrative reform, Roosevelt stated early in his presidency:

. . it's awfully erroneous to assume that it is in the reorganization of Departments and Bureaus that you save money. That is a very easy fallacy to fall into. Where 
you save money is by lopping off debts and lopping off employees and the spending of money. Savings through reorganization, at best, would be a drop in the bycket. . . The reason for reorganization is good management.

The national economic emergency took top priority during Roosevelt's first term in office, and, as a result, the questions of extensive executive reorganization were virtually ignored.* Although reorganization was momentarily postponed, the events of Roosevelt's first term in office shaped the temper of his later reorganization program which preoccuped his second administration. The dictates of the emergency demanded administrative strength in the areas of budget, personnel, and planning. As the New Deal took shape in the early years of Roosevelt's first administration, the budget, personnel, and planning increasingly became integral parts in the establishment of the welfare state. And when Roosevelt focused on the issues of reorganization in his second term, these administrative concerns expanded the dimensions of his previous conceptions on administrative management.

During the initial days of the New Deal, Roosevelt followed the traditional and orthodox policy of economic recovery--fiscal retrenchment and budget-balancing. The Economy Act of 1933 attests to this Rooseveltian view which sought recovery through the curtailment of government expenditures. 17

*Although the Economy Act of 1933 authorized the President to transfer agencies and bureaus, Roosevelt seldom used it. He issued seven executive orders which effected little change: he established the Office of National Parks and the Division of the Territories in the Department of the Interior; he abolished the U.S. Geographic Board and the Office of Alien Properties, and incorporated their duties in other departments and agencies; and he completely cancelled the U.S. Shipping Board and the Federal Employment Stabilization Board. Richard Polenburg, Reorganizing Roosevelt's Government (Cambridge, 1966), pp. 8-9. 
After his initial retrenchment policy, however, Roosevelt, on the recommendations of his advisers, promoted recovery through the expansion of federal services. ${ }^{18}$ In order not to burden the existing departments and agencies, Roosevelt created new ones to implement the policies of the first hundred days legislation. The AAA, NRA, TVA, PWA, HOLC, FDIC and other instruments of th early New Deal program both enlarged the administrative structure and greatiy expanded the scope of federal services. Wtih the emergence of these alphabetic agencies, and because of the nature of the depression which necessitated them, the budget, as an instrument of executive administration, became a significant tool of the presidency. Not only did Roosevelt utilize it in its traditional function as a projector of fiscal policy, but he also relied on it as a mechanism for "maintaining the economy. . ., for continuing improvement of operations, and for helping to make and enforce many decisions of the presidential office." 19 With the establishment of the welfare state by the measures of the second hundred days legislation of 1935, epitomized by the Social Security Act, the President's reliance on the budget, as an instrument of social and economic policy, was of paramount importance.

Because of this reliance on budgetary policy, the actions of the Comptroller-General served as a serious handicap to the implementation of executive policy. ${ }^{20}$ The Comptroller-General derived his power from his practice of preauditing proposed expenditures by federal agencies and departments. In order to avoid possible disallowance, the cabinet budget officers occasionally requested a pre-audit to determine the legality of an expenditure. Such procedures delayed administrative action until the Comptroller-General reached a decision, often bogging. 
down executive enactment indefinitely. Richard Polenburg notes the New Dealers's reaction to such practices:

New Dealers fully reciprocated this hostility. They denounced McCarl as a petty tyrant, who indulged in legal hair-splitting, arbitrarily held up needed funds, and snarled administration in reams of red tape. They complained that McCarl harrassed the TVA and failed dismally to provide Congress with an intelligible account of government operations. Administrators muttered that McCarl was "a reactionary Republican," surrounded by a "group of red-tape artists" whose "officials intermeddl ing" caused great damage.21

When Roosevelt considered executive reorganization during his second administration, both budgetary reform and the functions of the ComptrollerGeneral would be the focus of widescale attention and investigation.

In terms of the personnel which staffed the agencies and departments of the New Deal, Roosevelt demonstrated a remarkable ability to mobilize a host of intellectuals and professionals in Washington to direct the course back to recovery. ${ }^{22}$ In order to effect this swift mobilization, Roosevelt deliberately bypassed the Civil Service Commission whose function was to man the federal bureaucracy. ${ }^{23}$ During this period, the Commission was months behind in its work, controlled by obsolete testing and registers, and subject to veteran preferance. The emergency demanded quick federal entry not only to the existing bureaucracy but to the new agencies as well. As a result, more than four-fifths of the quarter of a million federal employees hired during Roosevelt's first administration were exempted from civil service regulations. ${ }^{24}$ Such a practice was an emergency or temporary measure at best. With the progression of New Deal policy which greatly enlarged the scope of federal responsibility and the federal bureaucracy, a personnel system was needed that did more than just make "certain, barring revolution, war or economic disaster, the chosen 
dullards could have a long, uneventful, thoroughly secure working life." 25

Roosevelt's attempts at coordination and planning among the bureaucracy of the executive branch failed repeatedly during his initial administration to bring about a cohesive and coherent executive policy. Instead, the formative years of the New Deal were typically characterized by the overlapping of duties, the contradiction of policy from one agency to the next, and the failure of the administration to respond to any widescale program of policy coordination. ${ }^{26}$ As in the other areas of administrative management, the dictates of executive efficiency were relegated to a position secondary to that of the national economic emergency. But "if Roosevelt was willing to defer systematic administrative improvement, other New Deal sympathizers regarded it with more urgency."27 Throughout his association with the National Resource Committee (NRC), Charles Merriam urged for policy planning that would lead not only to more efficient administration, but to more advanced social and economic planning as well. ${ }^{28}$ And as the New Deal scaled to size, Roosevelt turned to Merriam, in early 1936, to begin the long overdue task of forging some sense of coherency in the administrative operations. The problems and questions concerning the budget, the personnel system, and the functions of planning completed the agenda of Roosevelt's first comprehensive investigation of executive reorganization. ${ }^{29}$ This agenda, streamlined to the needs of both the administrative policies of the New Deal and the personnel which created these policies, consolidated those factors of leadership necessary to perpetuate and direct the new governmental organization of the welfare state. 
on March 20, 1936, Roosevelt sent letters of appointment to his Committee on Executive Reorganization to Charles Merriam,* Louis Brownlow, ${ }^{\star *}$ and Luther Gulick. ${ }^{\star \star *}$ This very choice of membership ensured both presidential involvement and acceptance as both Roosevelt and these chief committee directors shared similar ideas on the aims and purposes of the New Deal policies and the goals of reorganization. As one historian comments:

*Charles Merriam was educated in political science at Columbia University, taught at the University of Chicago 1900-1924, helped establish the Social Science Research Council in 1924, and served as a member on Herbert Hoover's Commission on Recent Social Trends before undertaking work on national planning during the New Deal with the National Resource Committee (NRC). See Barry Dean Karl, Executive Reorganization and Reform in the New Deal (Cambridge, 1963), pp. 37-81 for a.closer analysis of Merriam's work in politics and political science.

**Louis Brownlow had a long history of involvement with public administration. Having served as District Commissioner for Washington, D.C. (1915-1920), and as city manager in both Petersburg and Knoxville, Tennessee in the Twenties, Brownlow saw the need for the development of public administration to train governmental personnel in the fields of expertise necessary for public servants in the modern era. As a result of this thinking, Brownlow established the Public Administration Clearing House in Chicago--an institute dedicated to the goals of the professionalization of public administration and the investigation of government administration on all levels. See Karl, Executive Reorganization and Reform in the New Deal, pp. 82-126 for an indepth profile of Louis Brownlow.

***! Luther Gulick, educated at Columbia University Graduate School of Political Science, studied budgetary reform under Charles Beard, E.R.A. Seligman, and Henry Seager. Dividing his time among Columbia, the Training School for Public Service and the Bureau of Municipal Reform, Gulick acquired a vast expertise in budgetary policy and reform. From 1921 on, he served as the director of the Institute of Public Administration in New York City. See Karl, Executive Reorganization and Reform in the New Deal, pp. 127-165 for a discussion of Gulick's professional Tife and accomplishments. 
Their political views closely corresponded to those of the President. They were convinced that the American Presidency represented the most reliable bulwark against the tide of totalitarianism, that it was "the institution around and behind which democrats might rally to repel the enemy. .." To demonstrate that freedom and efficiency were linked, that democratic societies could act with promptness and vigor, the President must be given authority to match his responsibility. Congress should concentrate on setting down general principles; the President should be free to execute laws and administer the government. 30

With a staff of twenty-six experts, the Committee worked throughout the spring and summer of 1936 interviewing government personnel, investigating the existing executive structure, and submitting progress reports for evaluation and recomendation. ${ }^{31}$ Because of the nature of the Committee's work, it was compiled in secrecy so as not to politicaliy damage Roosevelt's chances for reelection on grounds that he was attempting some sort of "dictator coup" by promoting reorganization for his personal advantage. ${ }^{32}$ After the election of 1936 was over, the Committee presented its final report to Roosevelt.

The final report covered the areas of the budget, personnel, and planning which had become the more significant levers of administrative management of the welfare state. Its recommendations comprised the following points: the appointment of six executive assistants to lighten the burden of the president; a revitalization of the civil service by the expansion of the merit system, increased salaries for federal bureaucrats, and the replacement of the Civil Service Commission with an administrator; budgetary planning by granting authority to control accounts to the Executive, and the replacement of the Comptroller-General by providing Congress with an independent audit of all expenditures; the establishment of the NRC as a permanent planning and coordinating body 
in the Executive branch; and the reorganization of the executive branch by the creation of two additional departments--Public Works and Welfare--and the consolidation of all existing agencies and commissions under one of these departments. ${ }^{33}$ Roosevelt was in complete agreement with these recommendations, and in early 1937 sent the proposals to Congress for consideration and approval. 34

For two years the President's plans for reorganization were rejected by Congress, which saw the move as a usurpation of congressional power in violation of the guidelines of the Constitution. ${ }^{35}$ Although the congressional battle against reorganization lasted the better part of two years, Roosevelt persisted. The Reorganization Act of 1939, though considerably watered-down from the recommendations proposed in 1937, at least gave Roosevelt a new and more efficient organization to manage. As Tugwell notes: "For the first time the Presidency, as an operating mechanism, was something more than an informal group of assistants surrounding a principal." 36 During the Thirties, the presidency had become a highly institutionalized conglomerate of responsibilites and services which demanded a structure organized around the nature of the institution. 37 Until 1939 no organized leadership, save for the out-dated structure of the executive branch, existed in the federal government. With the implementation of the Reorganization Act at the end of the decade, the era of the institutionalized presidency began-a presidency suited to the needs of the new organization of the positive welfare state.

The Reorganization Act of 1939 created the Executive Office organized around three management branches: (1) Budget and Administrative 
Research; (2) Planning; (3) Personnel. These three administrative branches, together with the establishment of six positions of administrative assistants to serve the president, comprised the staff of the Executive office. 38

The Bureau of the Budget ${ }^{39}$ was divided into four main divisions dealing with the areas of management counsel, administrative and fiscal reorganization, investigation, and defense. Although Congress had failed to abolish the office of the Comptroller-General, the consolidation of the Bureau of the Budget in the Executive Office gave the president control over the creation and implementation of fiscal policy.

The transfer to the Executive Office of the NRC--renamed the National Resources Planning Board (NRPB)--established the objectives of planning and research as an integral factor in federal policy-making. 40 Equipped with the statistical expertise accumulated in the Twenties and Thirties, the NRPB served as an indicator of social and economic trends. As an investigative as well as planning body, the NRPB's primary function was to prevent widescale economic crisis by constantiy interpreting the economic and social indicators. In this capacity, the Board forshadowed the formation of the Council of Economic Advisers in later years. 41

The creation of an effective personnel recruitment body presented a challenge to Roosevelt. ${ }^{42}$ Congress had failed to grant him the authority to revise the civil service system, but the President surmounted the rejection by appointing one of his administrative assistants as a liason officer to the Civil Service Commission. The liason officer 
provided the Commission with reports on personnel deficiencies in various fields. These reports were instrumental in expanding the merit system in the deficient areas in order to ensure the necessary competency in the federal bureaucracy.

With the establishment of these three arms of administrative management, the top-level organizational framework of the executive branch advanced to a new dimension and met the needs of the welfare state. To further the coordination of the lower-level organization of the executive branch, Roosevelt established three new agencies: the Federal Works Agency; the Federal Security Agency; and the Federal Loan Agency. Under them, he transferred a 11 related bureaus and agencies. ${ }^{43}$ Thus, by the end of 1939, administrative reform, shaped by both its historical tradition and the dictates of the New Deal, enlarged the capabilities of the leadership in Washington, D. C. to guarantee the execution of the federal responsibilities inherent in the welfare state. Of this reorganization, one student of government concludes:

The Reorganization Act of 1939 converts the Presidency into an instrument of twentieth-century government; it gives the incumbent a sporting chance to stand the strain and fulfill his constitutional mandate as a one-man branch of our threepart government; it deflates even the most forceful arguments, which are still raised occasionally, for a plural executive; it assures us that the Presidency will survive the advent of the positive state. Executive Order 8248 may yet be judged to have saved the Presidency from paralysis and the Constitution from radical amendment. 44

Limited by Congress, Roosevelt achieved a remarkable success in equipping the executive branch of government with the necessary tools to perpetuate the new direction and relationship of the federal government to the nation. Created in the crisis of economic disaster in the early Thirties, the institutions of the welfare state encumbered the existing 
administrative structure which in turn jeopardized the success of these New Deal measures. The Reorganization Act of 1939 eased this contradictory situation between policy and administration, and secured the survival of the welfare state. More significantly, however, it assured the continuation or perpetuation of the new political elite of experts and intellectuals which had charted the course of federal policy throughout the New Deal years. With an organizational structure to complement and support the dictates of the utilization of social intelligence in a political context, this new elite was assured of an active role in the policyand decision-making channels in the executive branch. By 1935 the circulation of this elite into the strongholds of the national government had been realized; by the end of 1939 it was an integral factor in the institutionalized organization of administrative leadership. 


\section{ENDNOTES}

TGene M. Lyons, "The President and His Experts," The Annals of the American Academy of Political and Social Science, vol. 394 (1971), p. 40

${ }^{2}$ See Chapter Two, pp. for an analysis of the writings of Robert Michels.

${ }^{3}$ This is the thesis asserted by Richard Polenburg, Reorganizing Roosevelt's Government (Cambridge, 1966), pp. 3-6 and by Barry Dean Karl, Executive Reorganization and Reform in the New Deal (Cambridge, 1963), pp. vii-xilí.

${ }^{4}$ For additional development see Edward Hobbs, Executive Reorganization in the National Government (University, Mississippi, 1953), pp. 9-15.

${ }^{5}$ Harold T. Pinkett, "The Keep Commission, 1905-1909: A Rooseveltian Effort for Administrative Reform," Journal of American History, LII (1965), pp. 297-312.

${ }^{6}$ Karl, Executive Reorganization and Reform in the New Deal, pp. 15-16.

${ }^{7 \text { Ibid., pp. } 17-20 .}$

8 Rexford Tugwel1, The Enlargement of the Presidency (New York, 1960), pp. 364-367; 397-398.

${ }^{9}$ Hobbs, Executive Reorganization in the National Government, pp. 15-20.

${ }^{10}$ Tugwe11, The Enlargement of the Presidency, p. 364.

11 Ibid., p. 398.

${ }^{12}$ Karl, Executive Reorganization and Reform in the New Deal, pp. 250-253.

${ }^{13}$ Tugwell, The Enlargement of the Presidency, p. 399.

14 Ibid., pp. 400-402.

15 Bernard Bellush, Franklin D. Roosevelt as Governor of New York (New York, 1955), pp, 38-57.

${ }^{16}$ Quoted in Polenburg, Reorganizing Roosevelt's Government, p. 8. 
${ }^{17}$ William E. Leuchtenburg, Franklin D. Roosevelt and the New Deal (New York, 1963), pp. 45-46.

${ }^{18}$ See previous chapter for a discussion of the shifts in New Deal policy.

${ }^{19}$ Tugwe11, The Enlargement of the Presidency, p. 400.

${ }^{20}$ Harvey C. Mansfield, The Comptroller-General (New Haven, 1939), pp. $1-5 ; 70-75 ; 79-120 ; 274-277$.

${ }^{21}$ Polenburg, Reorganizaing Roosevelt's Government, p. 24.

${ }^{22}$ See previous chapter.

${ }^{23}$ Herbert Emmerich, "Personnel Problems in New Federal Agencies," Annals of the American Academy of Political and Social Science, vol. 189 (1937), pp. $119-125$.

24

Ibid., p. 119.

${ }^{25}$ Arthur M. Schlesinger, Jr., The Coming of the New Deal (Cambridge, 1959), p. 534.

${ }^{26}$ See previous chapter for a discussion of the National Emergency Council and the National Resources Committee.

27 Polenburg, Reorganizing Roosevelt's Government, p. 11.

${ }^{28}$ Karl, Executive Reorganization and Reform in the New Deal, pp. 77-79.

${ }^{29}$ Polenburg, Reorganizing Roosevelt's Government, p. 25; Karl, Executive Reorganization and Reform in the New Deal, p. 203.

${ }^{30}$ Polenburg, Reorganizing Roosevelt's Government, p. 11.

${ }^{31}$ Ibid., pp. 17-20.

${ }^{32}$ Tugwe 11, The Enlargement of the Presidency, p. 405.

${ }^{33}$ Report of the President's Committee on Administrative Management (Washington, D. C., 1937), pp. 57-54.

${ }^{34}$ Samuel I. Rosenman, The Public Papers and Addresses of Frankl in D. Roosevelt (13 vols., New York, 1938-50), IV, pp. 180-190.

${ }^{35}$ Tugwe 1, The Enlargement of the Presidency, p. 405; Polenburg, Reorganizing Roosevelt's Government, pp. 55-81; Karl, Executive Reorganization and Reform in the New Deal, pp. 277-266.

${ }^{36}$ Tugwe 11, The Enlargement of the Presidency, p. 407. 
37 Lyons, "The President and His Experts," pp. 36-37.

${ }^{38}$ A. J. Wann, The President as Chief Administrator (Washington, D.C., 1968), pp. 99-112; Edward H. Hobbs, Behind the President (Washington, D.C., 1954), pp. 10-13.

39 Wann, The President as Chief Administrator, pp. 106-107; Hobbs, Behind the President, pp. 21-75.

40 Wann, The President as Chief Administrator, pp. 108-109.

41 Rexford Tugwell and E. C. Banfield, "Government Planning at Mid-Century," Journal of Politics, 13 (May, 1951), pp. 153-160.

42 Wann, The President as Chief Administrator, p. 107; Hobbs, Behind the President, pp. 77-85.

43 Wann, The President as Chief Administrator, p. 107.

${ }^{44}$ Charles Rossiter, The American Presidency (New York, 1960), pp. 134-135. 


\section{CHAPTER VII}

\section{CONCLUSION}

"History is. . stability, stagnation, and decay, and each of these processes as well as historical change can be illuminated with the perspectives of elite theory." 1 Because of its universal assumption of minority rule, the elitist perspective offers a useful historical methodology for the analytical operation which guides historical inquiry. As this mode of scholarship attempts to uncover and trace the development of the centers of power and decision-making in the period under investigation, it allows for a broad overview of the historical process. In this manner, devoid of any dogmatic claims to a theory of history, the elitist perspective performs a valuable task in the ongoing process of historical interpretation and synthesis.

Viewing the New Deal within the parameters of the elitist perspective, one is able to discern the transitional role it played between the political dictates of an earlier era and the political demands of the modern age. The Thirties marked the evolution in the federal government from its traditional role of arbitrator or regulator of the nation's infrastructures to that of guarantor of the social and economic order. The Great Depression had precipitated this demand for the enlarged responsibilities of the federal government, and the New Deal facilitated the transition. Central to this process of change and transition, which characterized the scope of the New Deal, was the circulation into the federal government of a new elite of academics, especially social science-orientated intellectuals. Their 
impact was significant in terms of the legislation initiated and enacted, al though not all of the legislation itself proved successful in operation, the added dimension of social planning and social research within the federal government, and the restructuring of the administrative network of the federal government with the Reorganization Act of 1939.

Although the national government progressed in its ability to meet the challenges posed by the complex problems of the industrial order by the end of the decade, much work was still left undone. In many ways, the proliferation of the New Deal programs, at their peak in mid-decade, only underlined the pluralistic nature of the economic and social disorders of the nation. The solutions to massive unemployment, social inequity, and political disenfranchisement posed problems for the new elite of academics and social scientists, and these problems persisted despite the New Deal and despite the new administrative framework designed to ease the burdens of the management of the welfare state. Nevertheless, despite the many shortcomings and failures of much of the overall New Deal program, the New Deal did significantly alter the relationship between the government and the public. In this respect, the New Deal brought the federal government into the modern era by incorporating into the channels of national decision-making a new elite equipped with methodologies based on "social intelligence" which provided for at least the potential for rectifying the social and economic disorders of the nation. The New Deal ushered in a new chapter in the political history of the United States. With the realization of the welfare state and the furl implementation of the circulation of a new elite, a new set of directives and policy concerns strongly influenced the course of federal 
politics. Viewing the New Deal in this light, its failures can be assessed as the shortcomings inherent in attempting new alternatives to stabilize the economy and to promote social well being. Some of these New Deal failures, such as the programs of the NRA and AAA, fell drastically short in their goals of stabilizing the economic order, but then the emergency of the Depression at times forced the national government to forfeit long-range plans in lieu of short-range gains to keep the economy afloat.

The establishment of the welfare state by the new elite of social scientists and intellectuals had broad implications for the course of the federal government during the World War II years as well as in the post-war decades. These implications, too numerous and complex to analyze fully in these pages, are, nevertheless, important to mention briefly as they point out the significance of the New Deal experiment in the shaping of the contours of American History. Some of these outgrowths of the New Deal in the decades following the Thirties complete the remainder of this chapter.

Before many of the domestic problems of the nation were adequately assessed or resolved, the United States became involved in World War II. As was the case for the First World War, the federal government required a vastly expanded administrative staff to ensure a swift and efficiently managed war mobilization, Roosevelt mobilized "social scientists. . in key administrative posts, where their analytical skills were useful for the difficult and complex problems of managing the war effort." 2 In many respects, the war effort culminated in theory and practice much of the work promoted by social scientists during the New Dear. ${ }^{3}$ The war, by its 
enormous requirements, forced the government to deveiop and construct a complete set of social and economic indicators that took into account the whole of the economy. Because of this great advancements were achieved in the economic assessment of the potentials and possibilities implicit in the laws of economic growth which would govern the economy after the war. From the data compiled in the work of the War Production Board (WPB), the Office of the Price Administration (OPA), the War Labor Board, the War Manpower Commission, the Treasury Department, and the Bureau of the Budget, economists, statisticians, and other social scientists assimilated vast amounts of economic and social data pertinent to the management of a peacetime economy. Therefore, in late 1944, the federal government established the Office of War Mobilization and Reconversion (OWMR) as it was recognized "that intelligent planning for reconversion was dependent to a large extent upon a more effective administrative pattern for waging war." 4 This move to centralized planning for the reconverted economy helped ward off a repetition of an economic recession which crippled the nation after the conclusion of the First World War.

As was the case for many of the social science programs established to execute the wartime policy of World War I, the end of the Second World War saw the demise of many of the social science research and analysis programs in the federal government. ${ }^{5}$. But here the similarities stop. Before the start of the Second World War, social scientists and intellectuals were an integral part of the federal bureaucracy, and, at the war's conclusion, they still held on to many of the reins of power inherent in the decision-making process in the federal government. Although the war 
machinery was dismantled, the basic framework of welfare state government remained.

The war created "centralizing tendencies" in the federal government. which, during the course of the initial post-war decade, reinforced the infrastructures of the welfare state. This "crucial post war decade tested the viability of the welfare state hypothesis on a peacetime economy operating in a prosperous capacity. Initially the fear of a postwar recession molded the popular acceptance of a government regulated economy. ${ }^{6}$ In response to this fear, Congress, in 1946, passed the Employment Act which established a Council of Economic Advisers which provided the President with a professional staff of economists to oversee the matters of fiscal and monetary policy. This measure significantly altered the ad hoc and informal relationship which economists had shared with the President during the New Deal. With the establishment of the Council of Economic Advisers, this relationship between the President and his economic counsel was formalized and institutionalized within the Executive office and insured the consideration of economic policy within the scope of national decision-making.

The welfare state, as created by the New Deal, combined economic concerns with the formulation of social policy, and during the post war decade the social policy of the fledgling welfare state was expanded. The Fatr Deal of Harry Truman iniated and established a "comprehensive public housing program, revised upward social security benefits and extended coverage, increased the minimum wages, tightened price supports for farmers, and expanded programs for soil conservation, flood control, rural electrification, public power, and issued government assistance to veterans for education, homes and businesses.? 
By the end of the Forties, domestic issues shared the limelight with growing international concerns. The establishment of the United Nations, and the growing threat of communist encroachment on the Western world prevented an American isolationist policy. As leader of the "free" world contingent in the international forum, the United States was faced with formulating continuous international policy. To facilitate the formulation of foreign policy, the federal government, in 1947, established the National Security Council which "provided a channel through which systematic studies of American forelgn and military strategy entered the orbit of presidential power directly rather than through the diluting avenues of departmental positions papers. " 8 "With this position in international affairs, an added dimension of federal responsibility was placed within the scope of the welfare state. Not only was the federal government, and more explicitly the presidential orbit, entrusted with the responsibilities of the social and economic order, but with the international order as well. After 1950, these responsibilities of the federal government would shape the contours of presidential leadership.

The significance of the Eisenhower Administration regarding domestic issues was in its general acceptance of the directives of the welfare state. As Eric Goldman notes:

The new direction was plain in the highway, school, slumclearance, medical insurance, and widened social security bills sent to Congress. They were decidely un-New Dealish in the amounts of money called for, some of the methods proposed, and to the extent to which the Administration pressed for their passage. But they were also decidely non-Taftian in their assumption that the federal government had to assume responsibility for broad social needs. So far as the amount of expenditure was concerned, the programs would raise federal spending in these categories to an annual level four billion dollars higher than it had been under Truman. ${ }^{9}$ 
Although the Eisenhower Administration curtailed recruitment from the mobilized elite of academics and social scientists in Washington, 10 it performed a remarkable "holding action" in the continuation of welfare policies.*

The international tension of the Fifties prompted Eisenhower to expand federal programs to deal with the ever increasing possibilities of the outbreak of another war. During this period, there was a growing reliance on presidential advisers and the expansion of the Executive office through the incorporation of new agencies for scientific research. ${ }^{11}$ The inception of the Office of Science and Technology (OST) and the President's Science Advisory Committee (PSAC) were largely instrumental in developing the scientific and educational policies which preoccupied the nation after the USSR's launching of the Sputnik. The OST and the PSAC brought together the experitse of scientists and social scientists within the Presidential orbit in order to formulate domestic and foreign policy as necessitated by the nuclear age. By the close of Eisenhower's tenure in office, the responsibilities of the federal government in the postwar age were clearly defined as the guarantor of the domestic social and economic order and as the promotor of international stability abroad.

During the sixties, a prolifieration of social programs emerged on the domestic scene which had been sorely neglected in lieu of the more pressing international ivolvements of the previous decade. These new programs included the war on poverty, the refurbishing of urban America, the expansion of educational and health opportunities, and a reassessment of

* Much of the blacklisting of intellectuals during the Fifties was an outgrowth of McCarthyism. 
civil rights which had long been ignored by the federal government. ${ }^{12}$ The Kennedy and Johnson administrations employed social scientists in increasing numbers in task forces to analyze the social problems of the nation and to provide recommendations for improvement. The Sixties witnessed a resurgence in domestic and social reform, and in many ways brought to fruition the attempts of the New Dealers. From the New Frontier through the close of the Great Society, this remobilized elite sought to distribute the fruits of the prosperity of the age through the expansion of social and economic equality.

On the international front, The Vietnam war side-tracked the attention of the academic elite which caused for wide clevages among the ruling elite. In the initial years of the involvement there had been widespread elite support for American involvement in Vietnam, but in the years that followed this consensus developed into reassessments of the American posture in the war and recommendations for withdrawal. ${ }^{13}$ By the end of the decade, much disillusionment swept across the country manifesting itself in race riots, violent demonstrations against the war, and the youth opting for alternative life-styles with the counter-culture. There was a national reawakening--a wholesale questioning of the directives of federal policies in international affairs.

The easing out of the war during the initial years of the Seventies cooled domestic tensions, and for a while returned attentions to domestic issues and policies. But the uncovering of the Watergate scandal and the subsequent resignation of Richard Nixon added to the climate of national disillusionment sparked by the Vietnam involvement. This disillusionment in both domestic and foreign operations, around which the 
responsibilities of presidential power had been focused in the post-war era, has led to the questioning of the centralized decision-making process in the federal government, the instrument of the welfare state.

In the forty years since the incorporation of the welfare state, and the implementation of an elite of academics and social scientists into the federal government, a general acceptance of the directives of welfare capitalism has withstood the test of time. Whereas the Thirties marked the growth in the scope of federal responsibilities, perhaps the Seventies will witness a trend toward the accountability for the assumption of such responsibility. And according to the elitist perspective, inherent in the process of historical change, is the shift in the composition of the ruling elite. 


\section{ENDNOTES}

${ }^{1}$ Kenneth Prewitt and Alan Stone, The Ruling Elites (New York, 1973), p. 229.

${ }^{2}$ Gene Lyons, The Uneasy Partnership (New York, 1969), p. 83.

3 John McDiarmid, "The Mobilization of Social Scientists," in Leonard D. White, ed., Civil Service in Wartime (Chicago, 1945), pp. 74-80.

${ }^{4}$ Stephen Kemp Bailey, Congress Makes A Law (New York, 1950), p. 29.

5 Lyons, The Uneasy Partnership, p. 123.

${ }^{6}$ This thesis is asserted by Eric Goldman, The Crucial Decade--And After (New York, 1960).

7 Ibid., p. 95.

8 Gene Lyons, "The President and His Experts," The Annals of the American Academy of Political and Social Science, vol. 394 (197)), p. 41.

${ }^{9}$ Goldman, The Crucial Decade--And After, p. 281-282.

${ }^{10}$ Seymour E. Harris, The Economics of the Political Parties (New York, 1962), p. 25.

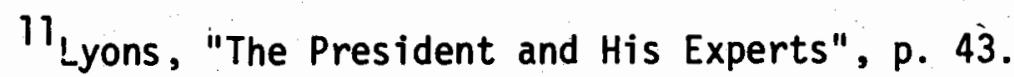

${ }^{12}$ See Jim F. Heath, Decades of Disillusionment (Bloomington, Indiana, 1975).

${ }^{13}$ Charles Kadushin, The American Intellectual Elite (Boston, 1972), pp. 123-195. 


\section{A SEIECTED BIB!IOGRAPHY}

Aristotle. Politics. Translated by Banjamin Jowett. New York, 1943.

B. P. "College Professors and the Public." Atlantic Monthly, LXXIX I1902), pp. 284-286.

Bailey, Stephen Kemp. Congress Makes a Law. New York, 1950.

Baritz, Loren. The Servants of Power: A History of the Use of Social Science in American Industry. Middletown, Connecticut, 1960.

Baruch, Bernard M. American Industries in the War. Washington, D. C., 1921.

Becker, Carl. Modern Democracy. New Haven, Connecticut, 1941.

Bellush, Bernard. Frankl in D. Roosevelt as Governor of New York. New York, 1955.

Blum, John. From the Morgenthau Diaries. Boston, 1959.

Bradford, F. A. "The Banking Act of 1935." American Economic Review, XXV (1935), pp. 661-672.

Braybrooke, David and Lindbloom, Charles E. A Strategy of Decision: Policy Evaluation as a Social Process. New York, 1963.

Burnham, James. The Machiavellians: Defenders of Freedom. New York, 1943.

Clapp, Gordon R. The TVA: An Approach to the Development of A Region. Chicago, 1955.

Clark, Kenneth B. Pathos of Power. New York, 1974.

Cobb, John Candler. "The Social Sciences." American Journal of Sociology, XXXI (1926), 721-32.

Conkin, Paul K. FDR and the Origins of the Welfare State. New York, 1967.

Corson, John J. and Paul, R. Shale. Men Near the Top: Filling Key Positions in the Federal Service, Battimore, 1966.

Croly, Herbert. The Promise of American Life. New York, 1909.

Dah1, Robert A. Who Governs? New Haven, 1961. 
Daniels, Jonathan. "Three Men in a Valley." New Republic, LXXXXVI (1938), pp. 34-37.

David, Alvin. "01d-Age Survivors, and Disability Insurance: Twenty-Five Years of Progress." Industrial and Labor Relations Review, XIV (1960), pp. 9-22.

David, T. Paul and Pollock, Ross. Executives For Government: Central Issues of Federal Personnel Administration. Washington, D. C.., T956.

Davidson, John Wells, ed., A Crossroads of Freedom: The 1912 Campaign Speeches of Woodrow Wilson. New Haven, 1956.

Dewey, John. Intelligence in the Modern World. New York, 1928.

Domhoff, William G. and Ballard, Hoyt B,, compilers. C. Wright Mills and the Power Elite. Boston, 1968.

Domhoff, William G. Who Rules America? Englewood Cliffs, New Jersey, 1967.

Dye, Thomas R., and Zeigler, L. Harmon. The Irony of Democracy. Belmont, Cal ifornia, 1970.

Eccles, Marriner. Beckoning Frontiers. New York, 1951.

Einaudi, Mario. The Roosevelt Revolution. New York, 1959.

Ekrich, Arthur A., Jr. Ideologies and Utopias: The Impact of the New Deal on American Thought. Chicago, 1969.

Emmerich, Herbert. "Personnel Problems in New Federal Agencies."

The Annals of the American Academy of Political and Social Science, vol. 189 (1937), pp. $119-125$.

Farley, James A. Behind the Ballots. New York, 1958.

Fifth Annual Report, The Social Science Research Council. New York, 1929.

Freidel, Frank. Franklin D. Roosevelt: The Apprenticeship. Boston, 1952.

Freidel, Frank. Franklin D. Roosevelt: Launching the New Deal. Boston, 1973.

Freidel, Frank. Franklin D. Roosevelt: The Ordeal. Boston, 1954,

Freidel, Frank. Franklin D. Roosevelt: The Triumph. Boston, 1956.

Fusfield, Daniel R. The Economic Thought of Franklin D. Roosevelt and the Origins of the New Deal. New York, 1956. 
Gaibraith, John Kenneth. The Great Crash: 1929. Cambridge, Massachussetts, 1955.

Goldman, Eric. The Crucial Decade--and After. New York, 1960.

Girvetz, Harry K. Democracy and Elitism: Two Essays with Selected Readings. New York, 1967.

Graham, Otis L., Jr. An Encore for Reform: The 01d Progressives and the New Deal. New York, 1967.

Graham, Otis L., Jr. "Historians and the New Deals." The Social Studies, LIV (1963), pp. 133-140.

Graham, Otis L., Jr., ed. The New Deal: The Critical Issues. Boston, 1971.

Harris, Seymour E. The Economics of Political Parties. New York, 1962.

Hawley, Ellis W. The New Deal and the Problem of Monopoly: A Study in Economic Ambivalence. Princeton, New Jersey, 1966.

Heath, Jim F. Decade of Disillusionment. Bloomington, Indiana, 1975.

Hobbs, Edward. Behind the President. Washington, D. C., 1954.

Hobbs, Edward. Executive Reorganization in the National Government. University, Mississippi, 1953.

Hofstadter, Richard. The American Political Tradition. New York, 1948.

Hofstadter, Richard. Anti-Intel lectualism in American Life. New York, 1963.

Horowitz, Irving Louis. Radicalism and the Revolt Against Reason. New York, 1961.

House, Edward Mandell and Seymour, Charles, eds. What Really Happened at Paris: The Story of the Peace Conference, 1918-1919. New York, 1921.

Hubbard, Preston J. Origins of the TVA. Nashville, 1961.

Hughes, H. Stuart. Consciousness and Society: The Reorientation of European Social Thought 1890-1930. New York, 1961.

Hughes, H. Stuart. Oswald Spengler: A Critical Estimate. New York, 1952.

"The Hullabaloo over the Brain Trust." Literary Digest, XVI (1933), pp. 8-9 Hunter, Floyd. Top Leadership USA. Chapel Hill, 1959. 
Hurd, Charles. When the New Deal was Young and Gay. New York, 1965. Jacobs, Charles E. Leadership in the New Deal: The Administrative Challenge. Englewood Cliffs, New Jersey, 1967.

"Jesse Jones." Fortune Magazine. XVI (1940), pp. 140-144.

Johnson, Hughs. The Blue Eagle from Egg to Earth. Garden City, New York, 1935.

Kadushin, Charles. The American Intellectl Elite. Boston, 1974.

Karl, Barry Dean. Executive Reorganization and Reform in the New Deal: The Genes is of Administrative Management, 1900-1939. Cambridge, T963.

Keller, Suzanne. Beyond the Ruling Class: Strategic Elites in Modern Society. New York, 1963.

Kirkendall, Richard S. Social Scientists and Farm Politics in the Age of Roosevelt. Columbia, Missouri, 1966.

Kolko, Gabriel. The Roots of American Foreign Policy. Boston, 1969.

Kolko, Gabriel. Wealth and Power in America. New York, 1962.

Krinsky, Fred, ed. Democracy and Complexity: Who Governs the Governors? Beverly Hills, California, 1968.

Lenski, Gerhard. Power and Privelege. New York, 1966.

Leuchtenburg, William E. Franklin Roosevelt and the New Deal. New York, 1963.

Leuchtenberg, William E. The Perils of Prosperity, 1914-1932. Chicago, 1958.

Link, Arthur, Wilson. The New Freedom. Princeton, 1956.

Lippmann, Walter. Public Comment. New York, 1929.

"Literary Men and Public Affairs." North American Review, CIXXXIX (1909), pp. 53-56.

Lyons, Gene M. "The President and His Experts." The Annals of the American Academy of Political and Social Science, vol. 394 (1971), pp. 36-45.

Lyons Gene M. The Uneasy Partnership: Social Science and the Federal Government in the Twentieth Century. New York, 1969. 
Machiavelli, Niccolo. The Discourses. Translated by Christian E. Detmold. New York, 1950.

Machiavelli, Niccolo. The Prince. Translated by Luigi Ricci and E. R. P. Vincent. New York, 1950.

Mansfield, Harvey C. The Comptroller-General. New Haven, 1939.

"Marriner Stoddard Eccles." Fortune, XI (1935), pp. 63-64.

May, Henry F. "Shifting Perspectives on the Twenties." Mississippi Valley Historical Review, XLIII (1956), pp. 405-427.

McCarthy, Charles. The Wisconsin Idea. New York, 1912.

Meisel, James H., ed. Pareto and Mosca: Makers of Modern Social Science. Englewood Cliffs, New Jersey, 1965.

Meisel, James H. The Myth of the Ruling Class. Ann Arbor, 1958.

Meriam, Lewis M. The Problem of Indian Administration. Baltimore, 1928.

Messner, Johannes. The Executive: His Key Position in Contemporary Society. St. Louis and London, 1965.

Michels, Robert. Political Parties: A Sociological Study of the 0ligarchial Tendencies of Modern Democracy. Transtated by Eden and Cedar PauT. New York, 1962.

Mi11, John Stuart. Representative Government. New York, 1935.

Mills, C. Wright. The Power Elite. New York, 1956.

Moley, Raymond. After Seven Years. New York, 1939.

Mosca, Gaetano. The Ruling Class. Translated by Hannah D. Kahn and Arthur Livingston. New York, 1939.

Mowry George. The Era of Theodore Roosevelt. New York, 1958.

Ogburn, William Fielding and Goldenweiser, Alexander, eds. The Social Sciences and the Interrelations. Boston and New York, 1927.

Pareto, Vilfredo. The Mind and Society. Translated by Andrew Bongiorno and Arthur Livingston. New York, 1935.

Pecora, Ferdinand, Wall Street Under Oath. New York, 1939.

Peeland, Roy and Donnelly, Thomas. The 1932 Campaign. New York, 1935.

Perkins, Frances. The Roosevelt I Knew. New York, 1946. 
Poe, J. C. "The Morgan-Lilenthal Feud." Nation, CXLIII (1936), pp. 885-886.

Pinkett, Harold T. "The Keep Commission, 1905-1909: A Rooseveltian Effort for Administrative Reform." Journal of American History, LII (1965), pp. 297-312.

Polenburg, Richard. Reorganizing Roosevelt's Government. Cambridge, Massachusetts, 1966.

Prewitt, Kenneth, and Stone, Alan. The Ruling Elites. New York, 1973.

Recent Social Trends in the United States: Report of the President's Research Committee on Social Trends. New York, 1933.

Report of the President's Comittee on Administrative Management. Washington, D. C., 1937 .

Report on the Committee on Recent Economic Changes of the President's Conference on Unemployment. New York, 1929.

Rice, Stuart A., ed. Methods in Social Science: A Case Book. Chicago, 1931.

Romasco, Aibert U. The Poverty of Abundance. New York, 1965.

Rosenman, Samuel I., ed. The Public Papers and Addresses of Franklin Roosevelt. New York, 1938-1950.

Rosenman, Samuel I. Working with Roosevelt. New York, 1952.

Rossiter, Charles. The American Presidency. New York, 1960.

Sabine, George. A History of Political Theory. New York, 1950.

Saunders, Charles B. The Brookings Institution: A Fifty-Year History. Washington, D. C., 1966.

Schattschneider, E. E. The Semi-Govern People. New York, 1960.

Schlesinger, Arthur, Jr. The Coming of the New Deal. New York, 1959.

Schlesinger, Arthur M. The Crisis of the 01d Order 1919-1933. Cambridge, 1957.

Schlesinger, Arthur M., Jr. The Politics of Upheaval. Cambridge, 1960.

Schwarz, Jordan A. The Interregnum of Despair: Hoover, Congress, and the Depression. Urbana, Illinois, 1970,

Seligman, Lester G. and Cornwell, Elmer E., Jr, eds. New Deal Mosaic: Roosevelt Confers with his National Emergency Council 1933-1936. Eugene, Oregon, 1965. 
Sorel, Goerges. Reflections on Violence. Translated by T. E. Hume and J. Roth. GTencoe, I7Tinois, 1950.

Stanley, David T., Mann, Dean E., and Doig, Jameson W. Men Who Govern: A Biographical Profile of Federal Political Executives. Washington, D. C., 1967.

Truman, David. "The American System in Crisis." Political Science Quarterly, LXXXIV (1969), pp. 488-495.

Tugwe11, Rexford. The Enlargement of the Presidency. New York, 1960.

Tugwe 11, Rexford. In Search of Roosevelt. Cambridge, 1972.

Tugwel1, Rexford and Banfield, E. C. "Government Planning at Mid-Century." Journal of Politics, 13 (1951), pp. 133-163.

Tugwe 17, Rexford G. The Democratic Roosevelt: A Biography of Franklin D. Roosevelt. Garden City, New York, 1957.

Turner, Frederick Jackson. The Frontier in American History. New York, 1920.

Twenty-fifth Annual Report, National Bureau of Economic Research. New York, 1945.

Unofficial Observer. The New Dealers. New York, 1934.

Wallace, Henry A. New Frontiers. New York, 1934.

Wann, A. J. The President as Chief Administrator: A Study of Franklin D. Rooseve Tt. Washington, D. C., 1968.

Wecter, Dixon. The Age of the Depression. New York, 1948.

White, Leonard D., ed. Civil Service in Wartime. Chicago, 1945.

Whitman, Willson. "Morgan and Morgan and Lilienthan." Harper's, 177 (1938), pp. 352-361.

Wilkinson, Rupert, ed. Governing Elites: Studies in Training and Selection. New York, 1969.

Wirth, Louis, ed. Decade of Social Science Research. Chicago, 1940.

Wolin, Sheldon S. Politics and Vision. Boston, 1960.

Wood, Neal. "Some Reflections on Sorel and Machiavelli." Political Science Quarterly, IXXXIII (1968), pp. 75-84.

Yerkes, Robert M., ed. The New World of Science: It's Development During the War. New York, 1920. 